\title{
LA INSOPORTABLE LEVEDAD DEL NUNCACOMER. PRIMERA PARTE: SANTAS Y BRUJAS
}

\section{THE UNBEARABLE LIGHTNESS OF NEVER-EAT. PART ONE: SAINTS AND WITCHES}

Carlos Gamero Esparza: Universidad Inca Garcilaso de la Vega (Perú). carlos.gamero@ozu.es

\section{CURRÍCULUM VITAE}

Reconocido Periodista peruano. Licenciado con Diploma de Honor en la Universidad Inca Garcilaso de la Vega.

\section{RESUMEN}

La anorexia no es una enfermedad de la Modernidad. Ya a finales del siglo XVI, Rosa de Santa María sometía su cuerpo al hambre y la tortura como vehículo para acercarse a Dios. Se acostumbró a consumir alimentos poco apetitosos y cada vez en menor cantidad. Pero dentro de esta enfermedad hay dos polos opuestos: París, la capital de la moda y la delgadez extrema, Biafra, la capital del hambre y los cuerpos esqueléticos, la tierra de los muertos. Más allá de lo puramente simbólico, hay una tragedia que empezó hace mucho tiempo y cuyas manifestaciones se ven hoy como una grotesca caricatura de la estupidez humana que llevó -y todavía lleva - a millones de jovencitas a morir prácticamente de inanición. Pero en el pasado, la coyuntura socio-cultural era distinta, sobre todo en la región europea, pero la enfermedad siempre fue la misma: privación sistemática del alimento con grave riesgo de la salud y la propia vida. A lo largo de la historia también ha habido falsas 
anoréxicas, famosos/as anoréxicas (un "ejemplo" en el que mirarse), y brujas, sí brujas. Algunos han venido a decir que parece que los síntomas de esta enfermedad no son propios de los tiempos posmodernos ya que han sido descritos y nominados en distintas épocas de la historia: brujas, santas, histéricas, anoréxicas, parecen ser algunos nombres que se le han dado a estas mujeres problemáticas que no se ajustan al discurso dominante de la época.

\section{PALABRAS CLAVE}

Anorexia - Modernidad - Hambre - Enfermedad - Brujas

\section{ABSTRACT}

Anorexia is a disease of modernity. Already in the late sixteenth century, Rosa de Santa María subjected his body to hunger and torture as a means to approach God. He got used to eating unappetizing and increasingly in smaller amounts. But in this disease there are two opposite poles: Paris, the capital of fashion and extreme thinness, Biafra, the capital of hunger and skeletal bodies, the land of the dead. Beyond the purely symbolic, there is a tragedy that began long ago and whose manifestations are today as a grotesque caricature of human stupidity that led, and still holds-a million girls almost die of starvation. But in the past, the situation was different socio-cultural, especially in the European region, but the disease was always the same: systematic deprivation of food with high risk of health and life itself. Throughout history there have been false anorexic, famous / as anorexia (an "example" which look), and witches, witches themselves. Some have come to say that it seems that the symptoms of this disease are not specific to postmodern times as they have been described and denominated in different periods of history: witches, saints, hysterical anorexia seem to be some names that have been problematic given that these women do not fit the dominant discourse of the time. 


\section{KEY WORDS}

Anorexia - Modernity - Hunger - Illness - Witches

\section{ÍNDICE}

1. Introducción

2. Historia incomible...

2.1. De Dioses obesos a Cristos flacos

2.2. Una santa (de tantas) que no quería comer

3. La era de la anorexia

4. La esquiva frontera entre la santidad y la brujería

5. Las falsas anoréxicas

6. El pueblo que no quería comer

7. Famosos/as y anoréxicos/as

8. El pasado de un futuro incierto

8.1 Habla la Antropología (Las brujas no comen lentejas... pero si "vuelan")

8.2. Habla la Sociología (la madre del cordero)

8.2.1. Sacerdotes y psiquiatras: balada para no comer

8.2.2. Médicos y sacerdotes

8.3. Habla el Psicoanálisis (Anorexia del somatismo)

8.4. Habla la Medicina (¿Anoréxicas? ¿Modelos? No Anoréxicas en Recuperación / No Modelos Exitosas)

9. La Medicina descubre la "caquexia de Simmonds"

10. ¿Sabía usted que...?

11. Apéndice

12. Procedencia de las imágenes 


\section{TEXTO:}

\section{Introducción}

A fines del siglo XVI, en Lima, Rosa de Santa María, nuestra Isabel Flores de Oliva, Patrona del Perú, América y las Filipinas, sometía su cuerpo al hambre y la tortura como vehículo para acercarse a Dios. Cuando un joven le dijo un día que era muy guapa, ella se provocó cicatrices en el rostro con pimienta picante. Cuando otro muchacho le habló de la belleza de sus manos, Rosa las sumergió en lejía para deformarlas. Se acostumbró a consumir alimentos poco apetitosos y cada vez en menor cantidad. En la pequeña choza levantada por sus padres en el jardín de su casa, su dura rutina consistía en doce horas de oración, diez horas trabajando y otras dos horas para conciliar el sueño en un rústico camastro.

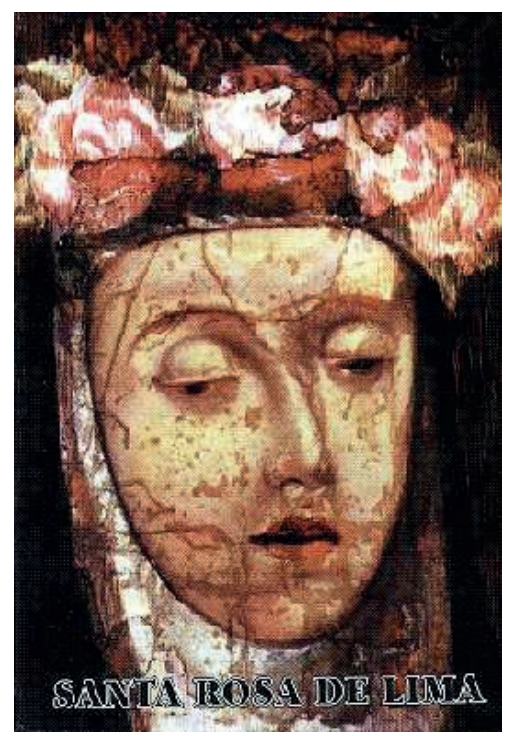

Imagen 1. Retrato post mortem de Santa Rosa, fresco de Angélico Medoro pintado instantes después de su muerte. Lima, 1617.

En el Siglo XIV y al otro lado del Atlántico, otra santa, Catalina de Siena, a sus 25 años, le escribió así a su confesor: "Querido padre, le agradezco toda la santa 
dedicación y el celoso cuidado que usted muestra hacia mi alma, porque me parece que usted se preocupa mucho cuando escucha cosas sobre mi vida (...) Usted me escribió aconsejándome que le pida a Dios que me haga comer. Y yo le contesto Padre mío, y se lo digo en nombre de Dios, que de todos los modos posibles yo me obligo a ingerir algún alimento una o dos veces por día (...) Muchas veces cuando hice lo que pude, me miro a mi misma para entender mi enfermedad y la bondad de Dios que por una gracia muy especial me permitió corregir el vicio de la glotonería..."

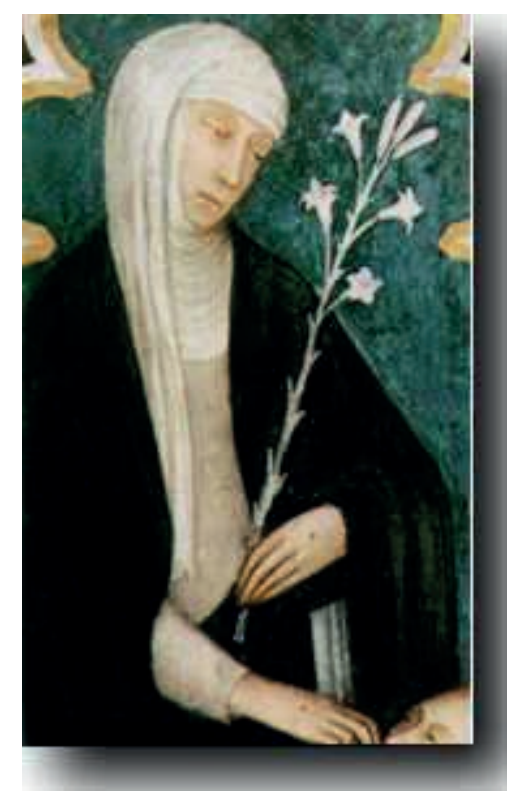

Imagen 2. Catalina de Siena. Estampita religiosa.

Desde tiempo inmemorial, la anorexia ha atacado a la humanidad, siendo más visible entre las mujeres $y$, aunque las circunstancias han variado de época en época y de sociedad en sociedad, la historia parece ser siempre la misma: una persona, casi siempre del sexo femenino, generalmente joven, siente repulsión hacia su propia figura: siendo delgada se ve "gorda" y opta por no comer. Sin duda un fenómeno viejísimo cuya comprensión ayuda a entender la psicología del nuncacomer presente. Y si en el pasado las mujeres no comían para llegar al cielo -o al aquelarre brujeril, en su defecto - , porque les habían enseñado que la comida predispone al pecado, en la actualidad no comen porque los estereotipos inventados por nuestra loca sociedad 
les han hecho creer que de otro modo irán al infierno del ostracismo y la marginación.

Tal vez una de las primeras especialistas del comportamiento humano que ha intentado bucear en los recovecos de la historia, para encontrar las respuestas de la anorexia en el pasado, ha sido la psicóloga argentina Silvia Fendrik, quien, en la introducción de su obra: "Santa Anorexia"1 escribe: "Usando el hambre como pasaporte, mirándose al espejo, leyendo ávidamente revistas de moda, estudiando dietas. Un buen día me di cuenta de que en esa trama intrincada y angustiante seguramente había símbolos cifrados a los que yo sólo podía responder 'nada'. Tal vez como un eco al 'deseo de nada' que la enseñanza de Lacan me había enseñado a reconocer en la anorexia. Pero fundamentalmente por ignorancia. Entonces me pregunté: '¿Qué es toda esta historia?' - Y me encontré con que no había Historia, sólo historias y más historias. Sólo un circuito infernal de imágenes, modelos, vómitos, kilos de más o de menos, abundante 'bibliografía', en fin, todo lo que hace a la moda - ¿París/New York/Buenos Aires/ o Biafra/Auschwitz?- Entonces, sin moverme de mi casa, decidí emprender un viaje al mundo de los muertos, y descubrí muchas cosas, entre otras cuántos cadáveres han quedado sin enterrar."

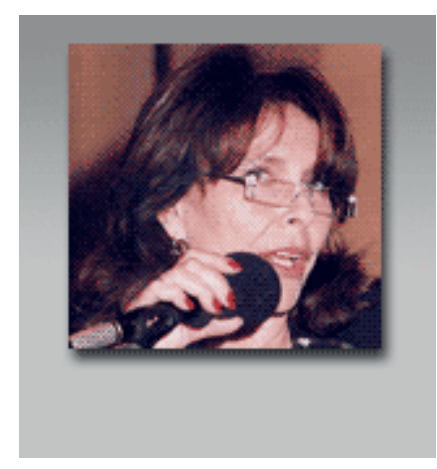

Imagen 3. Silvia Fendrik, la autora de "Santa Anorexia"

1 Editorial Corregidor, Buenos Aires. Portal Ambrosía. Enfoque psicoanalítico de los trastornos del hambre.
http://www.sfendrik.com.ar/ambrosia/index.htm 


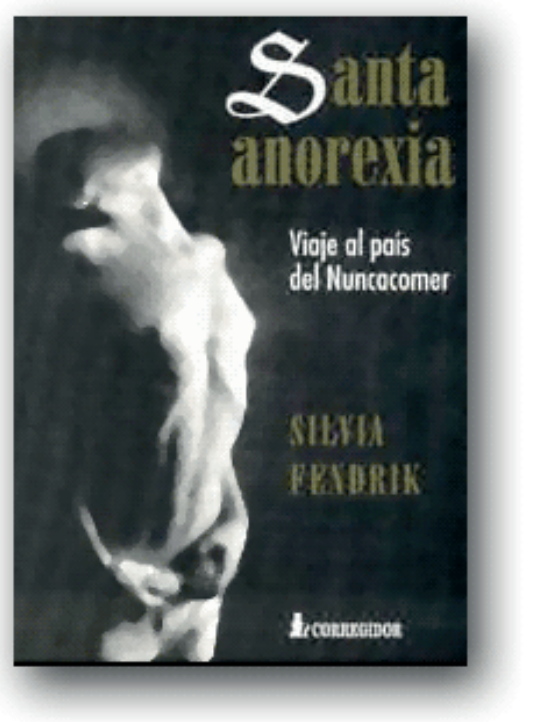

Imagen 4. La portada de su libro.

He aquí la sórdida geografía de lo incomprensible: París, la capital de la moda y la delgadez extrema, Biafra, la capital del hambre y los cuerpos esqueléticos, la tierra de los muertos. Los dos polos opuestos. El cielo y el infierno. Pero más allá de lo puramente simbólico, hay una tragedia que empezó hace mucho tiempo y cuyas manifestaciones se ven hoy como una grotesca caricatura de la estupidez humana que llevó -y todavía lleva- a millones de jovencitas a morir prácticamente de inanición. Pero en el pasado, la coyuntura socio-cultural era distinta, sobre todo en la región europea, pero la enfermedad siempre fue la misma: privación sistemática del alimento con grave riesgo de la salud y la propia vida.

La investigación llevada a cabo por diversos autores nos indica que la anorexia es una enfermedad ancestral y que durante milenios tuvo distintas connotaciones, entre éstas la religiosidad y el misticismo. El doctor Rafael Gómez-Cuevas, médico endocrinólogo de la Universidad Complutense de Madrid, nos lleva prácticamente a la prehistoria en su libro "Trastornos de la Conducta Alimentaria y sus Pequeñas Perversiones". Parece que en el Paleolítico, 40 mil años antes de Cristo, tener sobrepeso no era tan mal visto, es más, las deidades "gordas" de este periodo son frecuentes: casi todas estas "divinidades" tienen una cabeza redonda y pequeña, miembros muy cortos y una gran barriga, algunas con prominentes senos. Así se 
puede observar en la Venus de Willendoorf, la de Lausell, la de Lespugue --todas europeas-, y la de Mataumoto, en Japón, que son figuras cuya característica principal es la obesidad, "donde -es nuestra opinión - se daba culto al exceso de grasa, como significando una representación de vida, de fecundidad, para indicar que el exceso adiposo era en cierta forma como una señal 'divina' de salud y de longevidad, de grasa como signo de belleza, no -representación de una moda-, sino como necesidad de supervivencia.", afirma Gómez-Cuevas.

Asimismo, en otras culturas más tardías, la diosa fenicia Astarté también nos muestra su generosa anatomía adiposa. Pero no sólo en el viejo mundo podemos encontrar estas deidades. En tumbas prehispánicas del centro de Colombia se han encontrado curiosas estatuillas que parecen haber sido colocadas ex-profeso para acompañar al difunto en su viaje al más allá, como fue el caso de una extraña estatuilla de la diosa Bachué. Un ídolo femenino con atributos similares a los europeos.

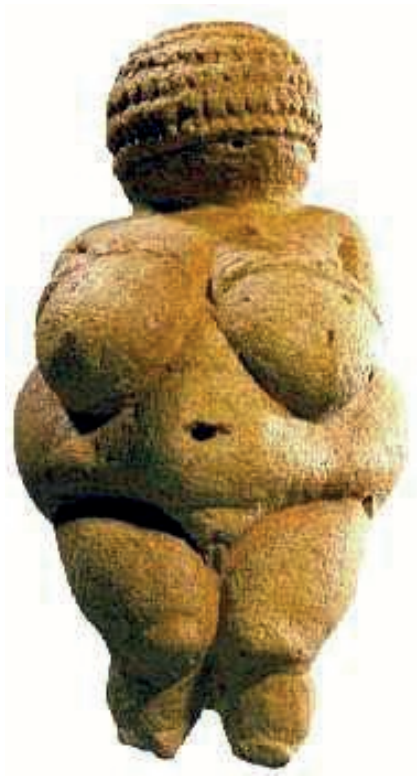

Imagen 5. Venus de Willendoorf (Austria), estatuilla de una diosa madre de la fecundidad, datada en 30.000 años antes de nuestra Era. Naturhistorisches Museum, Viena. 


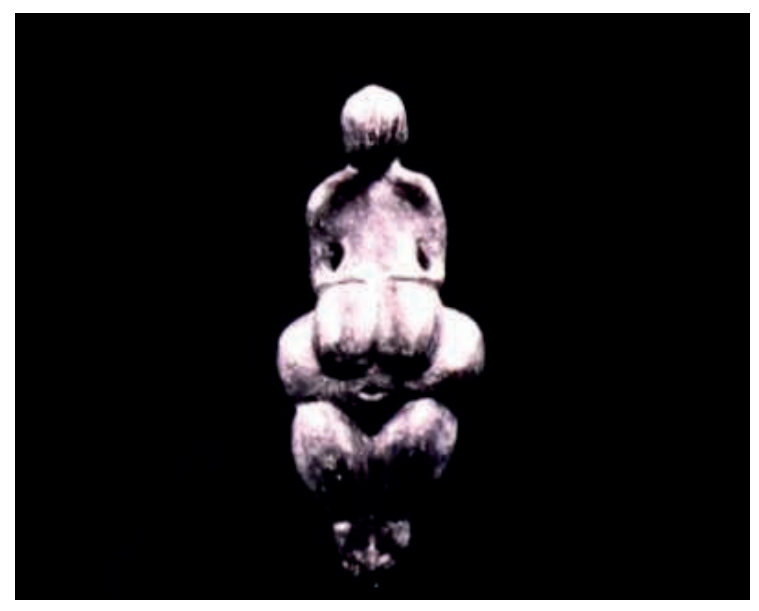

Imagen 6. Venus de Lespugue (Francia), diminuto ídolo con atributos maternales. Aproximadamente 25.000 a 18.000 años antes de Cristo. Musée de l'Homme, París

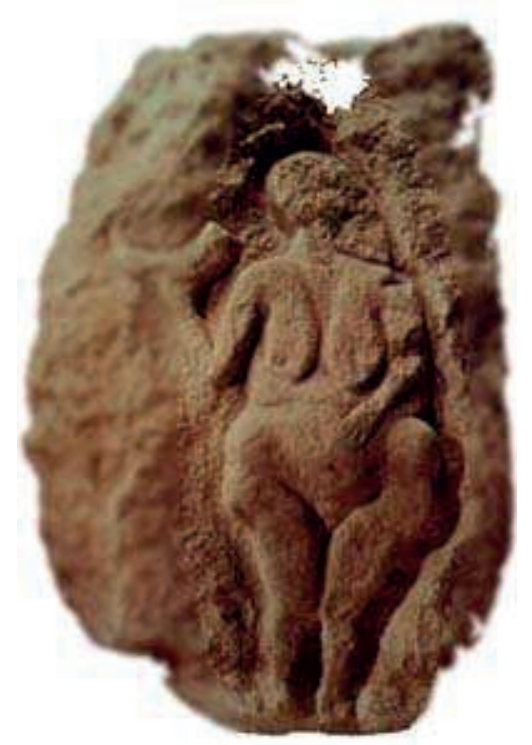

Imagen 7. Otra Venus gorda, la de Laussel, parece que era venerada por una sociedad de obesos. Encontrada en Dordoña (Francia). Aproximadamente 20.000 años antes de Cristo.

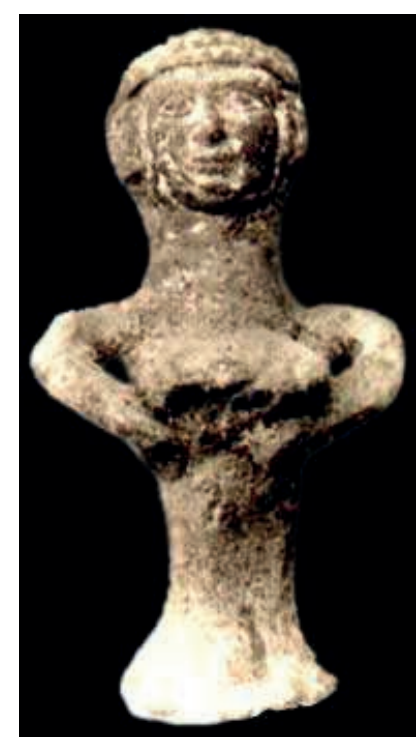

Imagen 8. La diosa fenicia Astarté tuvo "mala leche" en la Biblia, pero aquí nos muestra sus rollitos, como se puede apreciar en este ídolo cananeo. Alrededor de 1.300 A. de C. 


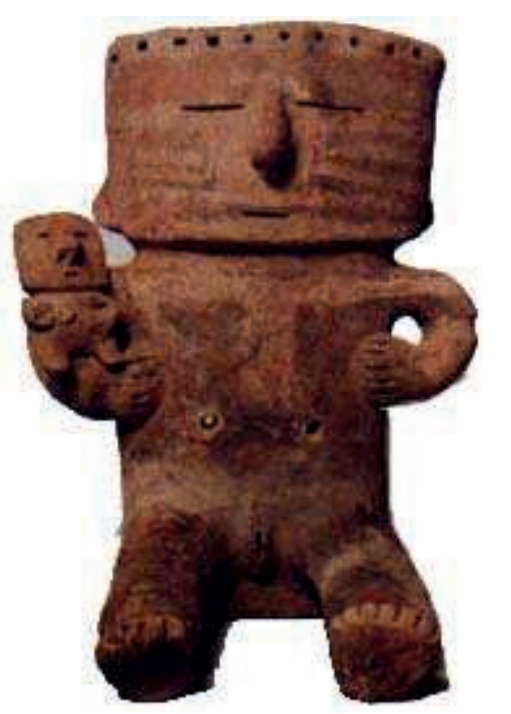

Imagen 9. Figurilla de arcilla de la diosa Bachué, considerada la madre de los chibchas colombianos. Museo del Oro de Bogotá.

\section{Historia incomible...}

\subsection{De Dioses obesos a Cristos flacos}

La imagen "gorda" de las divinidades ancestrales fue asimilada por los griegos -el mismo Baco es presentado como un dios juerguista y tragón-. Los romanos, tan amantes de la buena mesa y que tanto criticaban a los pueblos conquistados por sus "bárbaras costumbres" --entre estos, Celtas, Galos y Germanos-, se auto-inducían el vómito luego de los interminables banquetes a los que estaban acostumbradas las clases acomodadas. En pleno siglo X, Aurelianus describió al hambre mórbido como un apetito feroz con deglución en ausencia de masticación y vómito auto-provocado. En estos enfermos eran evidentes las grandes glándulas parótidas y la existencia de caries $^{2}$. No cabe duda que fue una antigüedad bulímica la que dio paso a otra anoréxica. La bulimia, prima hermana de la anorexia -palabra que viene del griego "bous", buey, y "limos", hambre, es decir: "hambre de buey" - fue algo normal en una sociedad donde incluso se rendía culto a los dioses de la buena comida.

\footnotetext{
2 "Los Orígenes de la Anorexia Nerviosa" Licenciada Valeria Matzkin (Buenos Aires). http://www.nutrinfo.com.ar/pagina/info/anorexi2.htm
} 


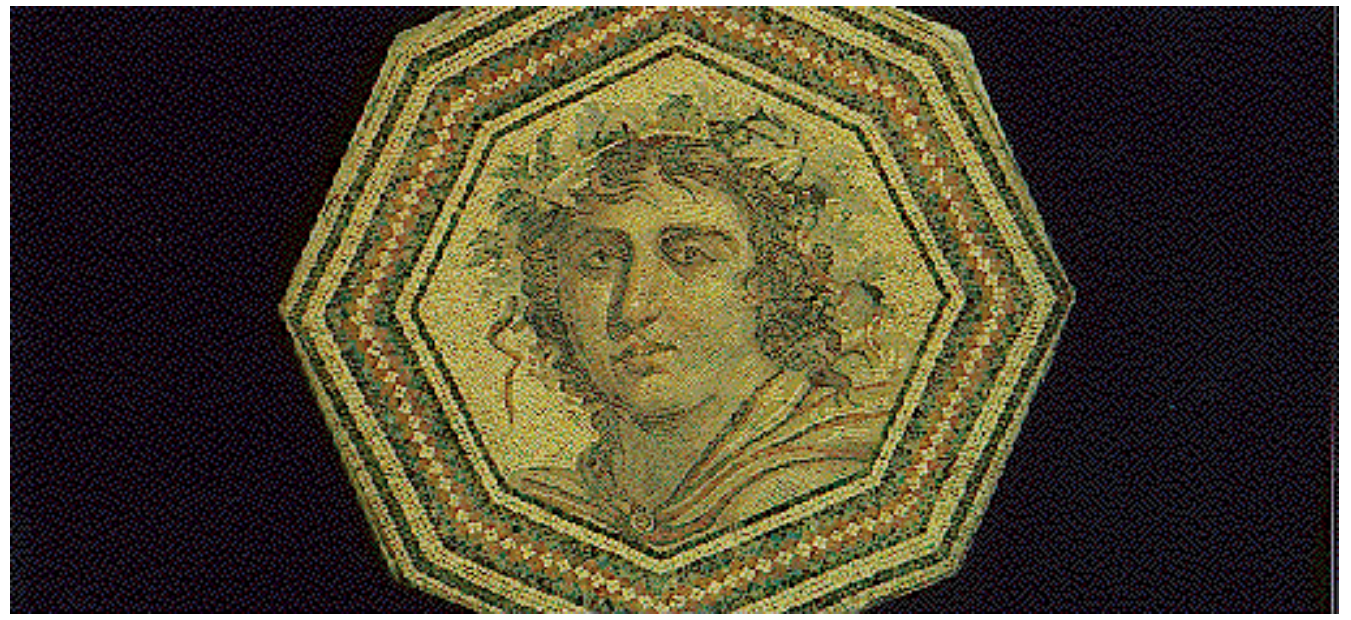

Imagen 10. Mosaico del dios Baco, Siglos III-II antes de C., conservado en el casco antiguo de Córdoba, España.

Pero esto cambió drásticamente con la llegada del cristianismo. Después del siglo III los cultos paganos fueron desterrados, sus templos derruidos y las iglesias ocuparon sus lugares. En los primeros años de la Edad Media ya no había dioses gordos sino diablos gordos y Cristos flacos. Así, la glotonería, antes ponderada, pasó a ser sinónimo de perdición. No en vano la gula se convirtió en uno de los siete pecados capitales. En plena Edad Media, la cosa se volvió endémica y los religiosos apremiaban a las jovencitas a ayunar, más aún si éstas profesaban votos de pobreza, castidad y humildad. La misma iconografía cristiana, como ocurrió por ejemplo con Hieronymus Bosch -El Bosco-, un pintor flamenco del siglo XV, representaba a la obesidad como algo pecaminoso, a la vez que la inquisición desataba cacerías humanas contra brujos, brujas y herejes. Mientras en la sociedad europea se extendía el ideal de la gordura como sinónimo de riqueza y poder, reyes gordos y vasallos gordos -el que podía, comía bien-, y en las iglesias, las homilías de los curas abominaban los pantagruélicos banquetes de los ricos poderosos; y en los monasterios, de ambos sexos, la anorexia ya estaba de "moda". "El rechazo al alimento se convirtió en la penitencia escogida para acceder al estado de máxima espiritualidad. Cuando se presentaban estos cuadros, la Iglesia solía llamar a médicos y sacerdotes, para establecer el grado en el que el ascetismo era una imposición espiritual con indicios de santidad. Santa Liduina (mística francesa 
muerta en 1433) se alimentó durante años con sólo un trozo de manzana, y Santa Wilgefortis, a fin de ahuyentar a los hombres, inició una dieta de inanición hasta que su rostro y cuerpo comenzaron a cubrirse de vello", escribe el doctor Pablo Cazau, docente en Psicología de la Universidad de Buenos Aires ${ }^{3}$.

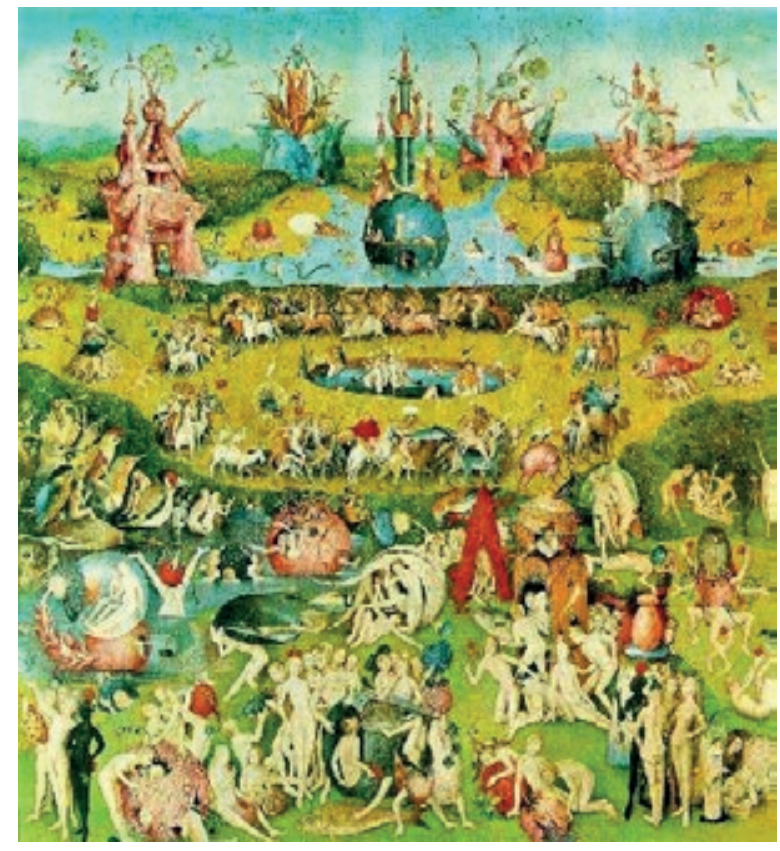

Imagen 11. En "El Jardín de las delicias", El Bosco reflejó una parodia de los siete pecados capitales, los placeres de la carne. Museo del Prado, Madrid.

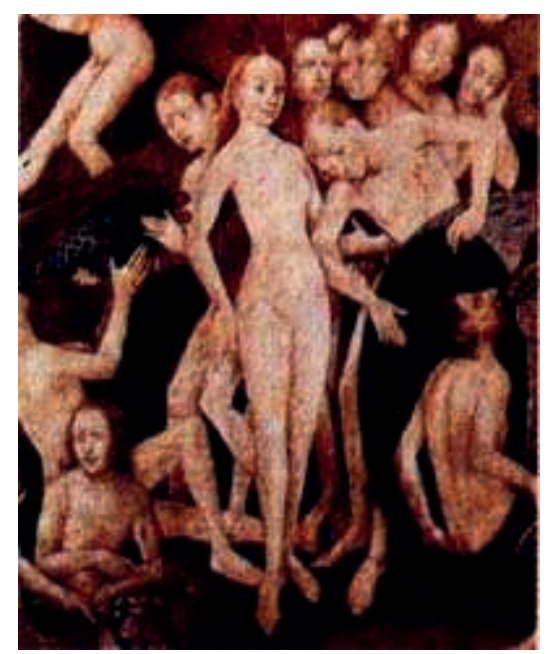

Imagen 11a. Un detalle del mismo cuadro anterior (centro de la parte inferior).

\footnotetext{
3 "Anorexia y Bulimia". Buenos Aires, mayo de 1999. http://www.galeon.com/pcazau/mo_psi010.htm
} 


\subsection{Una santa (de tantas) que no quería comer}

Por su parte, Javier San Sebastián Cabasés, Jefe de la Unidad de Psiquiatría InfantoJuvenil del Hospital Ramón y Cajal (Universidad Alcalá de Henares, España), nos remite al siglo IX, donde un monje de Monhein (Baviera) refiere la milagrosa curación de la joven Friderada, "que tras un periodo de apetito voraz deja de comer por completo, vomita los lácteos que ingiere y finalmente es curada por Santa Wilgefortis"4. Por la misma época, la historia de Santa Wilgefortis, una joven mártir portuguesa, más parece la descripción de un auténtico cuadro clínico de nuestro tiempo: "Era por el año 800 D.C. En una lujosa estancia de un castillo portugués, la hija del rey, rechazaba los alimentos que le ofrecían, ayunaba y si la forzaban a comer vomitaba. Enflaquecía a ojos vistas, y prácticamente se estaba dejando morir de hambre. Todo antes de romper su voto de castidad y de servir a Dios, todo antes que la casaran..." 5 . Sin duda, un caso típico de anorexia nerviosa que la convirtió en Santa Wilgefortis (del latin virgo fortis), o Liberata como es conocida en Francia, España y Portugal. Otra versión cuenta que venció su apetito como una expresión de su desinteresado amor a Dios.

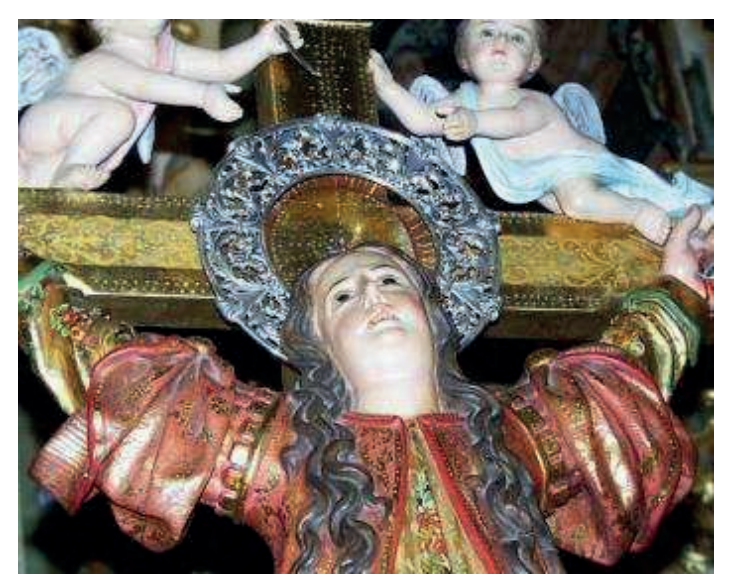

Imagen 12. Santa Wilgefortis o Liberata crucificada. Imagen que se venera en su santuario de Baiona (Portugal), localidad donde la santa fue martirizada.

\footnotetext{
4 "Aspectos históricos en la medicina sobre los trastornos alimentarios". http://www.msc.es/insalud/jovenes/aspectos_historicos.htm

5 "Trastornos de la Conducta Alimentaria y sus Pequeñas perversiones" Capítulo II. http://www.encolombia.com/medicina/libros/trastornos-gomez-cap2.htm
} 
Sobre este punto, Hubert Lacey, especialista en desordenes alimentarios del St George's Hospital Medical School de Londres, cuenta que "ella suplicó al Señor que la privara de toda belleza y Dios atendió su oración"6, por lo que el vello masculino se extendió por todo su cuerpo y le creció barba. En su afán de renunciar a su femineidad se privó del alimento "en orden a preservar su virginidad". Esta rebeldía, imperdonable en la Edad Media, hizo fracasar los planes matrimoniales de su padre, el rey de Portugal. Entonces, su pretendiente, el rey moro de Sicilia, rompió el compromiso pactado sin su consentimiento y, en represalia, su progenitor la hizo crucificar. Se dice que este martirio no solo repercutió en toda Europa, sino que comenzaron a surgir cultos basados en este hecho, inusual en aquella época -que se sepa, la crucifixión dejó de emplearse como método de ejecución tras la caída del Imperio Romano - y, una vez canonizada, fue ungida en muchos países como la patrona de las mujeres que desean verse libres de las apetencias masculinas. Lacey se pregunta, entonces, si esta historia, que más parece una leyenda fantástica, no habría sido realmente la de muchas mujeres que padecieron la misma enfermedad: anorexia nerviosa. Se especula que la referencia en esta historia a la aparición del vello masculino, tras el ayuno forzado, no sería otra cosa que una forma de masculinización bien conocida en la patología de la anorexia nerviosa crónica.

Ayunar, no comer, rechazar el alimento para llegar al cielo... este fue el "leiv motiv" de muchas mujeres y no pocos hombres, y el terco empeño empleado por las religiosas aspirantes a santas asustó a sus mismísimos confesores, como ocurrió con Catalina de Siena y muchas otras "colegas" suyas. Con justicia se podría llamar a la época en que vivió la santa de Siena como la era de las santas anoréxicas. Rudolph Bell en su libro "Holy Anorexia"7 describe la vida de 260 santas y beatas de la Iglesia

\footnotetext{
${ }^{6}$ Citado en "Anorexia Nerviosa en la Edad Media". http:// www.redmujer.com/cargar_salud.asp?nota=nota15

7 "Anorexia Mal de brujas y santas", publicado en la sección "Sociedad", diario La Nación de Buenos Aires, 02 de noviembre de 1997. Versión online: $\underline{w w w . l a n a c i o n . c o m . a r / s u p l e s / r e v i s t a / 971102 / r-133 . h t m ~}$
} 
Católica que tomaron el ayuno como una muestra de ascetismo y religiosidad, precisamente en este periodo. Asimismo, Nilda Guglialmi explica también que Rudolph Bell diferenciaba las actividades correspondientes a los hombres "que se libraban de pecados cometidos por sus cuerpos pero no insertos en ellos; en cambio las mujeres sacrificaban alimento para liberarse de sus cuerpos que estaban relacionados con lo material y lo impuro, con todo lo referido al sexo"8. Esto explicaría la actitud de muchas de estas mujeres que, además de negarse a comer, negaban también su propia naturaleza femenina.

\section{La era de la anorexia}

El caso particular de Catalina de Siena (1347 - 1380), hoy Doctora de la Iglesia, ha sido estudiado por los especialistas en trastornos alimentarios, no solo por haber sido un caso histórico sino porque, además, es un reflejo fiel de una realidad cuya continuidad se manifiesta ahora, siete siglos después de su muerte. Al igual que Wilgefortis, esta santa del siglo XIV, según Rampling ${ }^{9}$, tenía los síntomas típicos de la anorexia nerviosa. Entre los antecedentes que condujeron a la enfermedad había una fuerte relación simbiótica con su madre, que ansiosamente velaba por la apariencia física de su hija como el camino hacia el matrimonio, y la rebelión de Catalina cuando se abstuvo del alimento para evitar el "pecado" de su atractivo.

\footnotetext{
8 Universidad de Chile - Facultad de Filosofía.

http://www.uchile.cl/facultades/filosofia/publicaciones/cyber/cyber10/nguglielmi.html

The New York Times Rewiew. March 27, 1986. http:// www.nybooks.com/articles/5168

${ }^{9}$ Citado en "Anorexia Nerviosa en la Edad Media". $\underline{\text { http:// www.redmujer.com/cargar_salud.asp?nota=nota15 }}$
} 


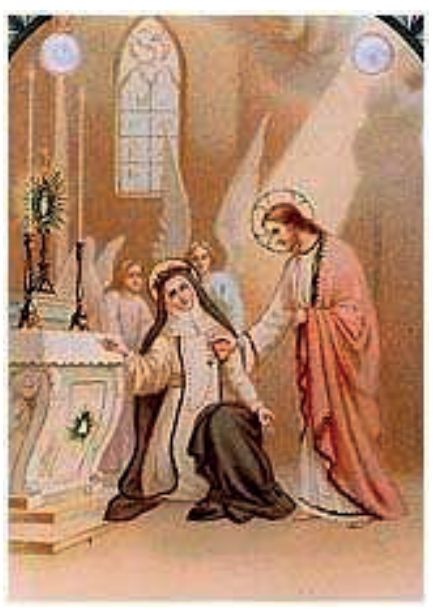

Imagen 13. Estampa antigua de Santa Catalina de Siena recibiendo al Corazón de Jesús.

Aunque los motivos que condujeron a esta santa a la desnutrición difieren de las anoréxicas actuales, que buscan el atractivo mediante la pérdida de peso, Catalina, además de no comer, se sentía obligada "a dejar una fina paja o alguna otra cosa comprimida bajo su garganta para provocarse el vómito", por lo que también se sospecha que haya tenido bulimia, pues la historia de su propia vida, reflejada en el testimonio dejado por sus confesores, revela sus trastornos alimentarios, los mismos que la habrían llevado a la muerte antes de cumplir los 33 años. Sus biógrafos cuentan que a los 7 años Catalina ya tuvo su primera visión de Jesús y al mismo tiempo comenzó a rechazar la comida, se impuso penitencias y manifestó su evidente rechazo al mundo, lo que asustó a sus padres. En la adolescencia, la futura santa ya sólo se alimentaba de hierbas y un poco de pan. Javier San Sebastián Cabasés ${ }^{10}$ presume que estas hierbas "constituyen con toda probabilidad sustancias laxantes para purgarse, al igual que la caña que utilizaba para producirse el vómito precedido en ocasiones de atracones". Su celo por la fe la hizo convertirse en consejera del papa Gregorio XI en Avignon, en un vano intento por impedir el Cisma de la Iglesia Católica, pero no logró convencer al pontífice para que regresara a Roma. Su fracaso la sumió en una gran depresión, dejó de alimentarse y murió al poco tiempo.

\footnotetext{
10 "Aspectos históricos en la medicina sobre los trastornos alimentarios".

http://www.msc.es/insalud/jovenes/aspectos_historicos.htm
} 
Se sabe también que Santa Clara de Asís (1194 -- 1253), realizaba unos ayunos tan severos que preocuparon incluso a su mismísimo maestro espiritual, San Francisco de Asís, quien, en cierta oportunidad, le pidió que comiera un poco más a pesar de que él mismo solía someterse a una rígida dieta alimentaria, casi a "pan y agua", ya que, al parecer, ella estaba sufriendo los efectos de la inanición. La historia cuenta que en los tiempos de San Francisco, muchos de sus seguidores fueron juzgados y condenados a la hoguera, ya que su estilo de vida ascética, similar a la de Jesús de Nazaret, no cuadraba con los cánones sociales y religiosos de una época que, como la actual, daba más importancia a lo material sobre lo intelectual. Un caso similar al de Catalina habría sido el de la heroína francesa Juana de Arco (1412-1431), la "doncella de Orléans", de quien se sabe se sometía a largos ayunos, incluso antes de sus acciones militares para liberar a Francia, sometida al yugo inglés durante la Guerra de los 100 años, tras haber escuchado "unas voces" que ella atribuía a Dios y que le ordenaban empuñar las armas por su patria. Pero finalmente fue traicionada y entregada a los ingleses, quienes la acusaron de hereje y bruja y la obligaron a "abjurar" de su fe, enviándola posteriormente a la hoguera en Ruan.

Algunos autores presumen que en el Nuevo Mundo se dieron casos de anorexia nerviosa entre religiosas, beatas y santas. Así ocurrió en el Perú con las llamadas "beatas iluminadas"11, unas mujeres que pretendían seguir el modelo de vida de Santa Rosa de Lima (siglos XVII-XVIII), y que fueron perseguidas por la Inquisición, y el de la mística y poetisa mejicana, Sor Juana Inés de la Cruz (1551-1695), de quien se dice que adoptó un régimen alimenticio donde sólo ingería agua y pan, el mismo que habría influido en sus estados alterados de éxtasis religiosos. Por su parte, para no perder la "costumbre", la santa española Teresa de Jesús (1515 - 1582) se hizo famosa por sus espectaculares éxtasis y levitaciones. Mientras sus biógrafos

\footnotetext{
11 "El Tiempo Simbólico de Santa Rosa de Lima". $\underline{\text { http:// www.colsantarosa.com.ar/2revista/revista.htm }}$
} 
religiosos vieron en su vida un ejemplo de espiritualidad y entrega a Dios, los especialistas, desprovistos de dogmatismo, han visto en su caso la enfermedad de los ayunos.

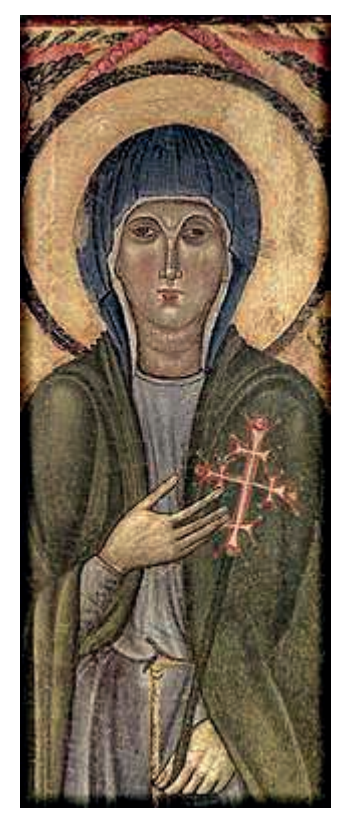

Imagen 14. Icono medieval de Santa Clara de Asís

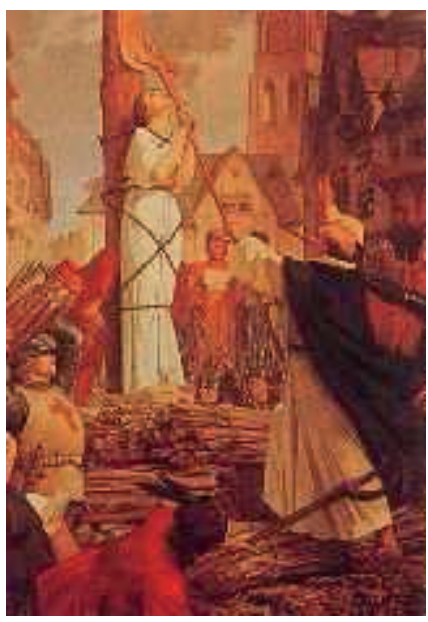

Imagen 15. Juana de Arco es quemada viva en Ruan, Francia (1431), después de ser procesada por supuesta brujería, cuando apenas tenía 19 años. Ilustración de época.

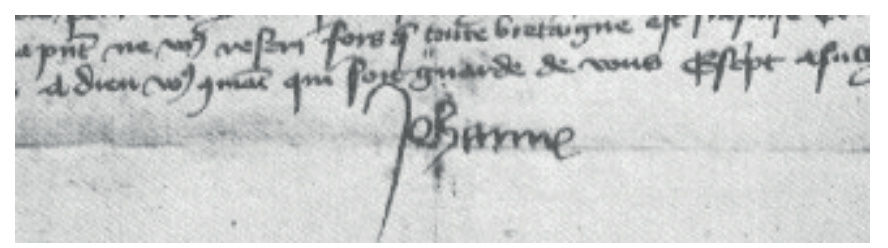

Imagen 16. Firma autógrafa de Juana de Arco en una de sus cartas al ejército inglés. Aunque es cierto que no sabía leer ni escribir, es muy probable que hubiera aprendido a escribir su nombre, así lo han demostrado diversos estudios grafológicos. 


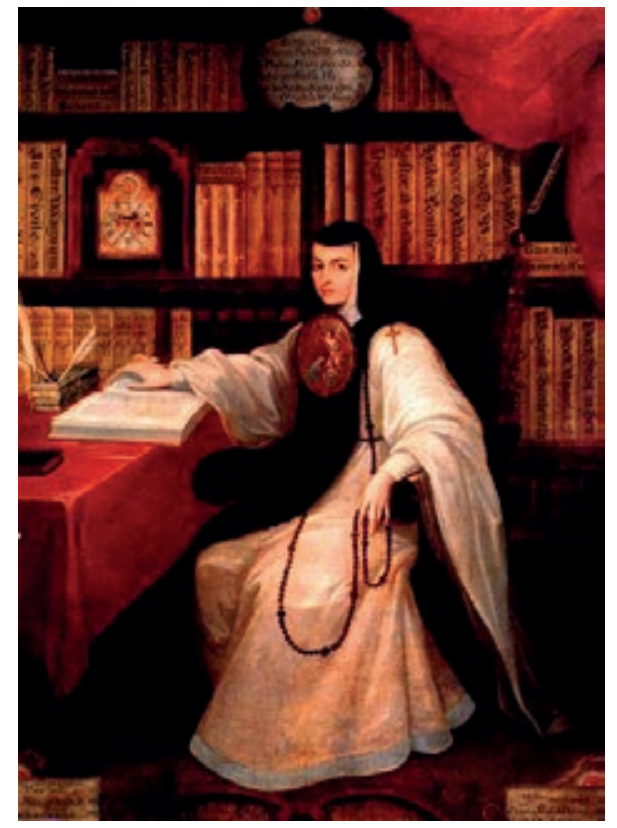

Imagen 17. Sor Juana Inés de la Cruz. Se dice que sufrió anorexia nerviosa, a pesar de su creatividad literaria.

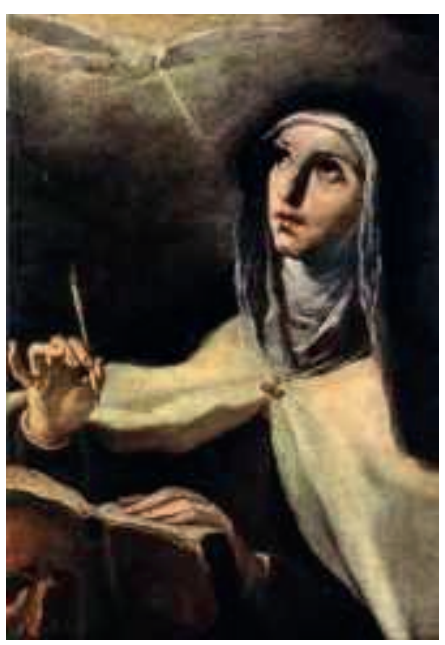

Imagen 18. Una santa que dejó huella, Teresa de Jesús fue una verdadera trotamundos y además creadora literaria a pesar de sus ayunos. Estampa de época.

Hasta el punto de morir de inanición, estas mujeres aisladas del mundo o recluidas en monasterios por imposición o voluntad propia, entretejieron la insólita historia de una patología que ha llamado la atención, hoy más que nunca, sobre los hábitos, costumbres y regímenes alimentarios del pasado, y la influencia que sobre éstos tuvieron las ideas religiosas y patrones sociales imperantes. La ciencia, antes que la teología o la hagiografía, ha puesto el ojo en la polémica sobre lo que antes era objeto de los miedos y supersticiones medievales. La anorexia pasó entonces, sino de señal de santidad, de posesión o de brujería, al rango de enfermedad. Ahora el problema era saber el porqué. El tema de las santas -y también de las brujas - anoréxicas 
configuró un insólito panorama social que, más allá de lo místico o profano, ha hecho las delicias de los estudiosos del comportamiento humano, que lo utilizan para comprender un poco más el problema actual de las millones de jovencitas anoréxicas que, bajo los dictados de la moda o la inconformidad, ya no por "amor a Dios" sino por el estereotipo social, se han convertido en un verdadero problema de salud pública en este loco comienzo del tercer milenio. "El sentido fenomenológico de la enfermedad -escribe San Sebastián Cabasés - era, en estos casos, el mismo que después manejó de alguna manera el psicoanálisis: la renuncia al cuerpo con caracteres sexuales y, en consecuencia, fuente de placer y atracción libidinal, en aras de conseguir una absoluta individualidad; un sentido de la existencia marcado por la penitencia, el sacrificio y también la productividad intelectual y artística. Es decir, a través de la restricción y de la purga, se conseguía la pérdida de cualquier rastro de feminidad potencialmente pecaminosa, elevándose el espíritu hasta el misticismo. Se trataba de mujeres ascéticas, resistentes, alejadas del mundo material, con una fuerza interior que les permitía sobrevivir a las privaciones, aún desarrollando una gran actividad"12.

\section{La esquiva frontera entre la santidad y la brujería}

"La voluntad de hierro para sostener que no se trataba de un capricho y para negar la importancia del alimento para vivir parece acercar llamativamente a Catalina de Siena a las jóvenes anoréxicas de fines de nuestro siglo y también pone en evidencia la dificultad de diferenciar nuestra moderna religión 'diet' de los estrictos cánones alimenticios que regían en los conventos medievales", señala Fendrik en su libro "Santa Anorexia". Y es que, muy a pesar de los confesores de las santas, que les pedían comer para estar bien con Dios, éstas replicaban diciendo que era Dios el que les daba fuerzas para no comer. Esta opinión aparece corroborada por la doctora

\footnotetext{
12 "Aspectos históricos en la medicina sobre los trastornos alimentarios".

http://www.msc.es/insalud/jovenes/aspectos_historicos.htm
} 
Nilda Guglielmi, de la Academia Nacional de Historia Argentina, quien señala en su ensayo "Mujeres y Piedad"13 que "el rechazo del alimento implicaba la negación de lo material en que se incluía la vida sexual. Era un elemento que ayudaba al logro de la perfección en que se ejercía, de manera evidente, la voluntad. Los sacrificios alimenticios, las privaciones a que se sometían las mujeres devotas moldeaban sus cuerpos de tal manera que les quitaban las características propias de su sexo, un cuerpo, que simbolizaba la materia contra lo espiritual del cuerpo masculino."
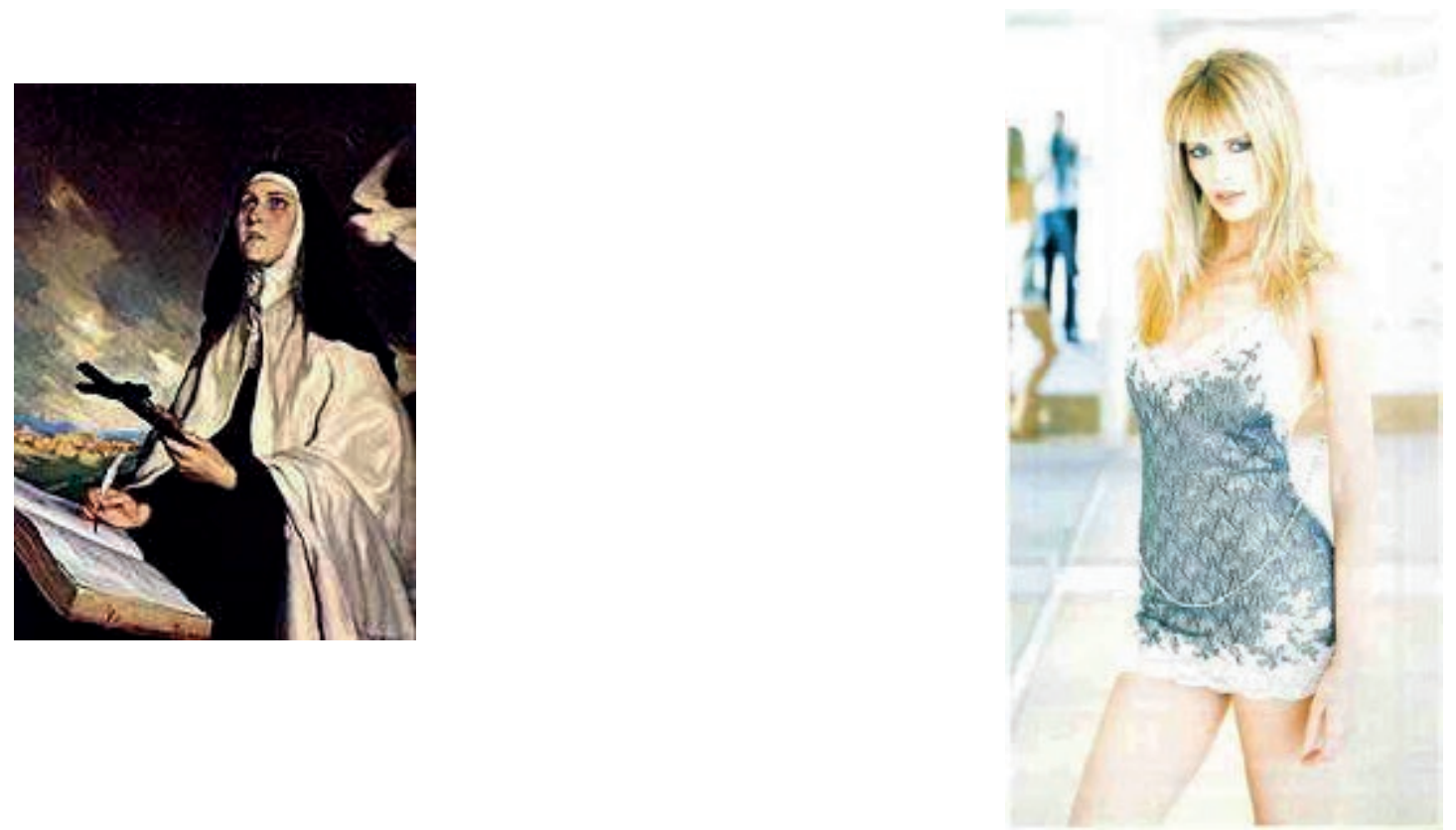

Imágenes 19a. -- 19b. ¿Qué diferencia hay entre santas como Teresa de Ávila y una "top model" como Claudia Schiffer? Una dejó de comer por "amor a Dios", la otra por no perder la línea... y por "amor al status"

La relación entre la negativa a comer y la destrucción de la identidad femenina a través de un ayuno a ultranza no hace sino corroborar lo planteado por muchos

\footnotetext{
${ }^{13}$ Universidad de Chile - Facultad de Filosofía.

http://www.uchile.cl/facultades/filosofia/publicaciones/cyber/cyber10/nguglielmi.html
}

The New York Times Rewiew. March 27, 1986. http:// www.nybooks.com/articles/5168 
autores, de que la renuncia a sí misma fue también una forma de expiación, de purificación espiritual, como queda corroborado en un reportaje publicado en el matutino bonaerense "La Nación"14, donde Silvia Fendrik, la autora de "Santa Anorexia", manifiesta que, durante su investigación sobre el pasado de esta enfermedad, le sorprendió el hecho de que el "nuncacomer" fuera algo que se institucionalizó entre las santas de los siglos XIII y XIV e incluso el XV (Santa Clara de Asís, Santa Catalina de Siena, Santa Teresa de Ávila, entre otras). "Había muchas jóvenes que tomaban a las santas como modelo de identificación. La única manera de acercarse a ellas era dejar de comer. Hoy lo sabemos porque a partir del siglo XIII los confesores llevaban registros que hoy son verdaderas historias clínicas".

Las santas, desde Clara de Asís en el medievo hasta Teresa de Jesús, desafiaban los ayunos y las dietas autorizadas por la Iglesia. Para ellas, la pureza y la santidad estaban asociadas a estados místicos de privación que se expresaban especialmente en un comer-nada que las hacía sospechosas de estar poseídas. ¿Por Dios o por el diablo? Y los confesores no sabían qué hacer para responder a esta pregunta, situación que animaba a las religiosas a seguir adelante, por considerar que el hecho de no encontrar respuesta en sus propios consejeros espirituales no era otra cosa que el "sí cómplice" de Dios para continuar su ayuno sin fin.

\footnotetext{
14 "Anorexia Mal de brujas y santas", publicado en la sección "Sociedad", diario La Nación de Buenos Aires, 02 de noviembre de 1997. Versión online: $\underline{w w w . l a n a c i o n . c o m . a r / s u p l e s / r e v i s t a / 971102 / r-133 . h t m ~}$
} 


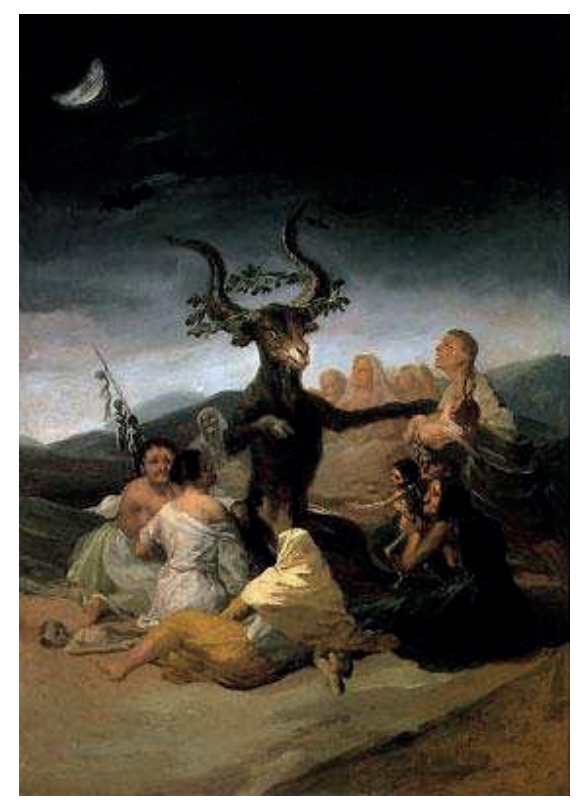

Imagen 20. Muchas religiosas fueron hechas pasar por brujas debido a que prácticamente vivían sin comer y decían que Dios las ayudaba a sobrevivir. Escena de "El Aquelarre" de Francisco de Goya, pintado entre 1795 y 1798. Museo Lázaro Galdiano, Madrid.

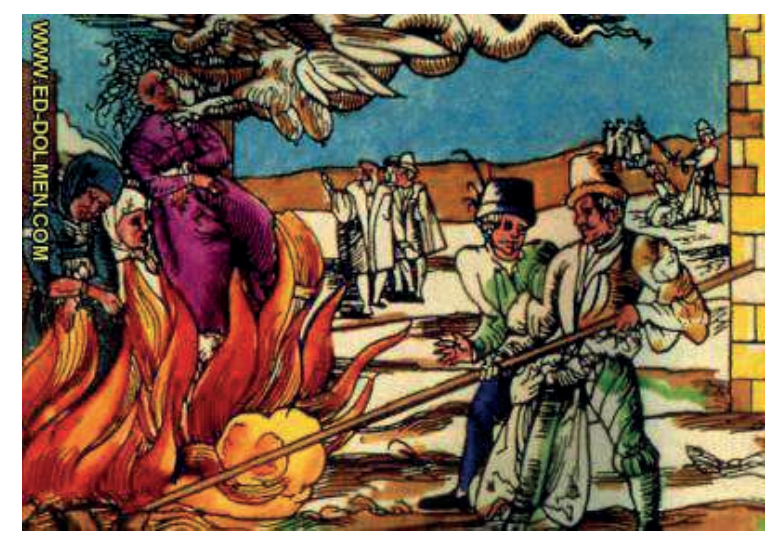

Imagen 21. Quema de brujas por la Inquisición en la Alemania del siglo XVI. Grabado de época.

¿La ingesta, entonces, es o era sinónimo de posesión divina o posesión diabólica? Sin duda, aquello era un gran dilema espiritual que atormentó a los teólogos durante siglos pues no podían juzgar nada sin el riesgo de meter la pata y cometer una 
barbaridad... como las de la Inquisición. La misma autora continúa diciendo que "entre el siglo XVI y el XVIII se cometió un holocausto contra las mujeres, acusadas de brujas, que en la cultura popular están representadas como viejas esqueléticas. Por eso yo establezco una continuidad en el país de nuncacomer entre santas y brujas." Era pues evidente que no se podía controlar a todas ni se podía establecer realmente si una joven religiosa que no comía no era lo que parecía. "La Iglesia - prosigue Fendrik - tenía una enorme preocupación por ese estado de privación alimentaria. Las chicas trasgredían las normas del ayuno, aquel que servía para purificar el espíritu. La cuestión estaba en el límite. Tanto que la Iglesia temía estados de posesión diabólica. La semejanza entre la auténtica religiosa y la poseída por el demonio era muy difícil de establecer, en primer lugar porque ambas acreditaban poderes sobrenaturales y, sobre todo, compartían un lugar común: vivir casi si alimentarse, con la consiguiente sospecha, cargada de curiosidad y angustia, de clérigos y laicos, de doctos y legos, según las épocas".

\section{Las falsas anoréxicas}

Para poder comprender la relación entre lo religioso y lo brujeril, había que responder a esta grave cuestión: ¿cómo entender, entonces, la relación entre la santidad y la anorexia, sin meter las cuatro, o peor las cinco? Y contra el empeño de los teólogos en resolver este enredo espiritual, estaba la llamada vocacional que atrajo a muchas mujeres a la vida monacal. "La vocación por el convento -explica Fendrik - se despertaba en estas jóvenes muy tempranamente, lo que algunos historiadores que investigan la historia de las mujeres en Occidente interpretan como un importante recurso de la Edad Media para escapar de los designios de esa sociedad patriarcal que las obligaba a casarse muy jóvenes con hombres a los que no conocían"15.

\footnotetext{
15 "Anorexia Mal de brujas y santas", publicado en la sección "Sociedad", diario La Nación de Buenos Aires, 02 de noviembre de 1997. Versión online: www.lanacion.com.ar/suples/revista/971102/r-133.htm
} 
En este estado de cosas, nadie podía arrogarse la capacidad de saber delimitar la difusa materia del espíritu, con el riesgo de caer en el descrédito. Un exceso de celo podía llevar a la hoguera a una verdadera religiosa, confundida por bruja. Y un exceso de ayuno podía poner en peligro la propia vida. Ni los más conspicuos exegetas lograron resolver el serio problema que planteaba la renuncia de la comida y sus subsecuentes fenómenos... por un lado, ayunos que duraban días, meses e incluso años, y, por el otro, las experiencias místicas que estas últimas decían tener. Eran fenómenos incomprensibles para la mayoría, fenómenos de los que, curiosamente, no se habla hoy. Y uno no puede dejar de preguntarse el porqué... ¿Por qué hoy, como ayer, determinados síntomas de la anorexia, como las alucinaciones, no se repiten? Fendrik explica que tales visiones estaban ligadas a una mística cultural. En la brujería sucedía lo mismo que con la vida religiosa: "Las chicas creían que estaban poseídas por el demonio. Son fenómenos muy extraños de identificaciones colectivas." Y como era de esperar, la temible Inquisición, nada ajena al tema, tomó cartas en el asunto: "Cuando la Inquisición puso en la mira a las anoréxicas, comenzó una terrible caza de brujas. Tenía un temor de que a través de determinados signos, incluso la flacura, estas chicas saliesen del círculo reproductivo."

Pero uno de los puntos más importantes que trata Fendrik en su libro es el de las falsas anoréxicas. En el invierno de 1807, cuando ya se creía que las brujas eran cosa del pasado -aunque todavía se recordaba los trágicos sucesos de Salem, en Massachusetts, donde, en el siglo XVII, decenas de mujeres fueron quemadas vivas en la hoguera acusadas de brujería - se hizo público que Ann Moore, una mujer de un pequeño pueblo de Estados Unidos, conocida por su vida licenciosa, vivía sin comer.

La mujer decía que estaba ayunando para expiar sus pecados pasados y sus asombrados vecinos observaron que no parecía sufrir los estragos del hambre. Con 
esto muchos se convencieron de que se trataba de una facultad milagrosa. ¡Se la veía tan bien! Incluso logró hacer que se intentara demostrar científicamente que existía la posibilidad de que una persona pudiera vivir del aire, patraña con la que llegó a acumular una pequeña fortuna con las donaciones que le hacían los aldeanos que la creían una santa. Pero, con el tiempo todo se supo: La mujer en realidad se alimentaba utilizando pañuelos empapados en aceite y vinagre que la propia hija le hacía llegar a escondidas.

Este fue el primer caso documentado de una anorexia ficticia. Esto nos lleva a preguntarnos ¿qué es lo que realmente mueve a las jóvenes a decidir ser anoréxicas? "Es un enigma" dice Fendrik, quien a lo largo de la investigación para su libro "Santa Anorexia" llegó al punto de que toda explicación se agota. "Yo creo -prosigue - que hay cuerpos portadores de mensajes inmemoriales, que los llevan sin saberlo. Mediante la privación alimentaria se está expresando algo que tiene que ver con pautas culturales ligadas con la feminidad. Lo primero que aparece en el tiempo en que una chica pasa de la pubertad a la adolescencia, haciendo una dieta estricta, es el fantasma de la anorexia. Como si ser mujer fuera ser anoréxica".

La centuria del 1800 fue una de las que más interés concitó en la psicología del comportamiento humano, y es precisamente en este contexto donde Fendrik señala que "en ese entonces la flacura estaba asociada con una especie de modelo cultural de elegancia -si no que lo digan las revistas sociales del París de las últimas décadas de aquel siglo, la capital mundial de la cultura y la moda de entonces - . La conjunción entre el modelo poético y el modelo de la aristocracia está nada menos que en ‘La dama de las camelias' que fue un best seller". Lo cierto es que hoy, en este loco comienzo del tercer milenio, a pesar de toda la experiencia acumulada sobre los trastornos alimentarios, todavía no se puede decir que se conoce para qué sirve ser anoréxica. "Para averiguarlo se necesita tomar distancia y tener una perspectiva histórica. Aunque en estas últimas décadas hubo una redefinición de lo que significa 
ser mujer, también en la Edad Media y en el siglo pasado (XX) se redefinió su lugar en la sociedad", concluye Fendrik.

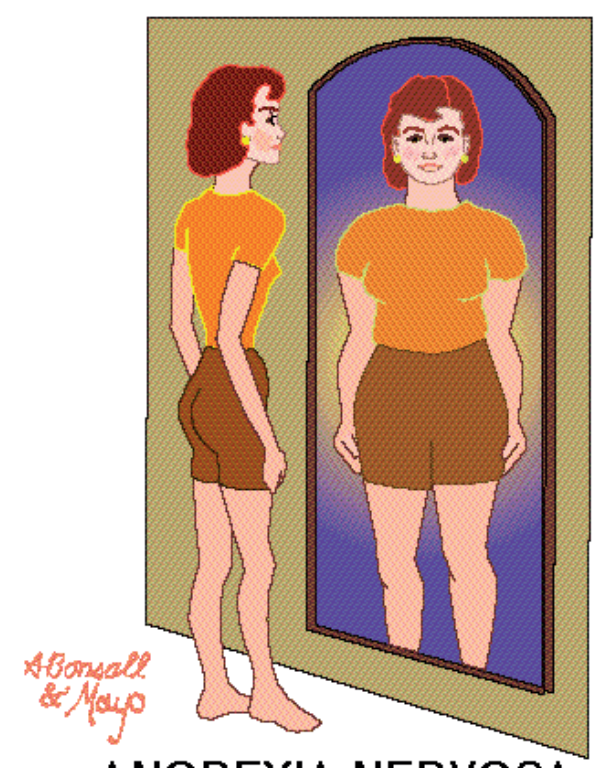

Imagen 22. ¿No es acaso la misma cosa, verse en el espejo de su estereotipo o en el de la salvación, el nuncacomer pasado y el nuncacomer de ahora?

\section{El pueblo que no quería comer}

Las "poseídas" de Morzine (Una epidemia de posesión demoníaca en el siglo XIX).

"En el siglo del progreso, cuando las "posesiones" se creían ya desaparecidas de la faz de la tierra, las "poseídas" de Morzine interpretarán un libreto que evoca el mismo teatro diabólico que había presenciado Europa en siglos anteriores, cuando alrededor de las poseídas se apretaban filas de exorcistas, de inquisidores, y de todo tipo de gente absolutamente convencida de la existencia del demonio. En esos "antiguos tiempos" de apenas uno o dos siglos antes, los médicos no se involucraban o, si lo hacían, de ningún modo se autorizaban a afirmar que podía tratarse de enfermedades y no de estados de posesión diabólica. En Morzine, en cambio, la Iglesia rechazará públicamente el recurso al exorcismo y exigirá la intervención de los médicos. Éstos dictaminaron que se trataba de típicos casos de demoniomanía. 
Dicha enfermedad consistía en secreciones de fluido nervioso, que provocaban convulsiones y pensamientos insensatos, atribuidos a su vez a los efectos nefastos de una religión mal interpretada por las ignorantes o muy sugestionables mentes de las mujeres campesinas. Algunos médicos propusieron un nombre más complicado: histerodemonopatía epidémica. El objetivo es doble: por un lado nombrar a la enfermedad para poder clasificarla dentro de las categorías diagnósticas (nosografía) recientemente establecidas. Por otro, enseñar a las jovencitas a reconocerse a sí mismas y a ser reconocidas por los médicos y las familias y los vecinos, bajo ese nuevo nombre.

Todo es nuevo: un nuevo saber y una nueva identidad que pretende sustituir a las creencias tradicionales, al mismo tiempo que instruye, cumple funciones pedagógicas, decide el grado de riesgo, somete a su tutela a aquellos que aún viven en la ignorancia de siglos anteriores. Y, como en el caso de las poseídas de Morzine, también recurre, cuando lo necesita, a las autoridades militares.

En el siglo XIX el discurso religioso ha perdido su influencia frente al discurso médico que es ahora quien tiene la última palabra en materia de fenómenos convulsivos, o de cualquier otro padecimiento del cuerpo. Pero los fenómenos colectivos de posesión no han desaparecido del todo, como tampoco han desaparecido las maneras de pensar que los atribuyen a la aparición del demonio. En Morzine - de allí su interés actual- confluyen las tensiones latentes entre el poder médico, la Iglesia, la mentalidad popular y el poder político. Cada una de esas instancias tendrá un efecto directo en lo ocurrido. Todo indica que es la primera vez en la historia que el saber médico va a intentar -y finalmente lograr- imponerse sobre las creencias religiosas y populares interviniendo directamente en la vida cotidiana. Será un combate largo y difícil. Y probablemente lo sucedido no habría pasado a los archivos de la historia si las autoridades eclesiásticas y civiles no hubieran recurrido 
a los médicos, luego de que el cura local se negara rotundamente a continuar ejerciendo en Morzine la vieja práctica del exorcismo.

¿Qué fue lo que ocurrió? Algunas jovencitas de un colegio de monjas -y más tarde muchas mujeres y también algunos hombres de la aldea-, comenzaron a sufrir ataques en los que blasfemaban, insultaban, se arrastraban por el piso, pretendiendo estar siendo poseídas por el diablo. Habían dejado de comer, y vomitaban cuando se las obligaba a hacerlo. Con un lenguaje obsceno, las niñas también vomitaban insultos a Dios y reclamaban la atención del cura, exigiendo a gritos ser exorcizadas Pero éste se negó y pidió auxilio a los médicos. La reacción del pueblo a esta negativa fue violenta y los casos, ya de por sí numerosos, se multiplicaron inmediatamente. El cura fue atacado por las poseídas y por numerosos fieles. Los hospitales -también las cárceles en los casos más "rebeldes"- se llenaron de enfermas. Nadie sabía muy bien qué hacer con ellas. La epidemia tomó tales proporciones -casi la mitad de la población femenina fue afectada - y tardó tanto tiempo en ser dominada -alrededor de veinte años- que puso en jaque a todos los que intervinieron, tanto médicos como autoridades civiles y militares. Sus tácticas cambiaban todo el tiempo, de punitivas a curativas, de pedagógicas a coercitivas. El mal a veces parecía ceder, pero sus rebrotes fueron una constante, durante esos largos veinte años. Sin embargo terminó por desaparecer. Los médicos triunfaron. Las demonópatas se sometieron a los criterios de la ciencia y se adaptaron a ser simples histéricas. Las pocas que continuaron resistiéndose fueron rebautizadas como "erotómanas" y su destino fue el hospital psiquiátrico. En una palabra, la enfermedad perdió finalmente su carácter de epidemia y el asunto cayó en el olvido. Sin embargo, los periódicos de la época, suizos, franceses, e ingleses, que hoy pueden consultarse, ofrecen testimonios abundantes de la gran resonancia que tuvieron esos acontecimientos.

Diez años más tarde, Charcot, nombrado titular de la cátedra de Clínica de las Enfermedades Nerviosas en la Salpetrière, en 1882, comenzará a trasmitir en forma 
de espectáculo sus investigaciones y sus conclusiones sobre la histeria. Un discípulo de Charcot, Bouchet, hará su tesis de psiquiatría en 1899, y se referirá a los sucesos de Morzine, clasificándolos dentro de un cuadro nosológico que a esa altura ya había sido reconocido y bien definido con lujo de detalles por Charcot como "gran histeria".

A su vez los sucesos de Morzine serán mencionados por el diccionario enciclopédico Gran Larousse, como ejemplo del último caso conocido y definitivamente superado, de "demonopatía". Por nuestra parte los hemos incluido como ejemplo paradigmático de la enorme tensión que se produce entre los distintos discursos, cuando de jovencitas que no comen se trata. Aunque el tema del rechazo a alimentarse de las poseídas de Morzine parezca secundario o quede desdibujado - $u$ olvidado en medio del escándalo de las blasfemias a Dios y otro tipo de obscenidades- recordemos que era el signo inconfundible, el primer signo, de la aparición del extraño mal.

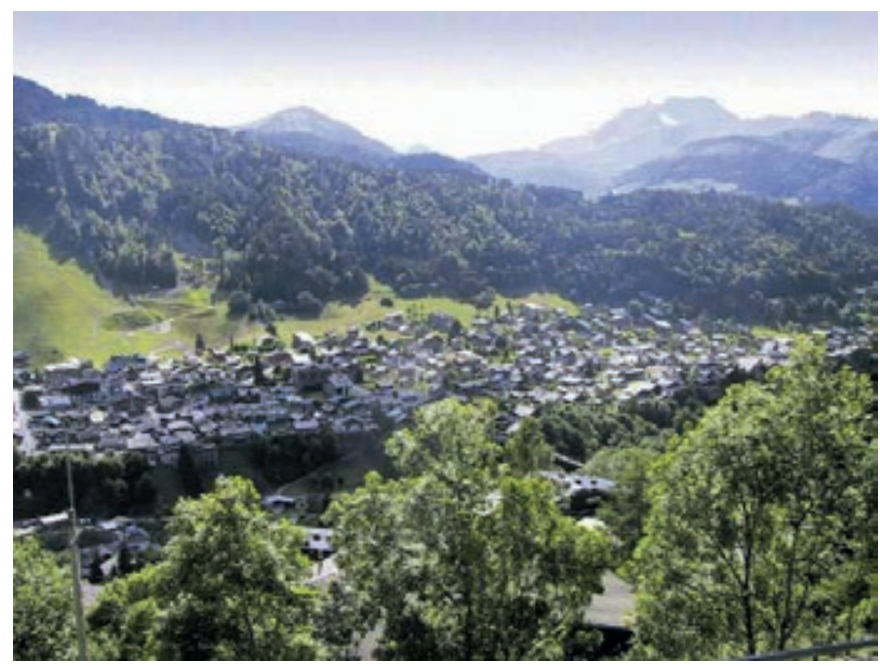

Imagen 23. Morzine, el pueblo de las famosas "poseídas" es ahora un encantador paraje turístico del Pirineo francés ${ }^{16}$

\footnotetext{
16 Página Web de Morzine, Francia. http:/ / www.morzine-avoriaz.com/
} 
¿Cuál era el rasgo más característico de la posición médica en esos tiempos? Al igual que en nuestro días, los doctores de aquel entonces estaban persuadidos de representar los logros de la civilización frente a un estadio cultural "inferior", es decir el saber y la razón por sobre los prejuicios y la ignorancia. Su objetivo es obvio: demostrar que todo tiene una explicación racional: en el clima, el tipo de alimentación, las condiciones geográficas, las creencias supersticiosas, los virus o las bacterias, se encuentran la o las causas que favorecen o determinan la aparición de la enfermedad. En Morzine fueron muchos los médicos que intentaron probar hasta qué punto las ideas de posesión son consecuencia del fanatismo y de la ignorancia. Pero como el discurso médico nunca es del todo homogéneo, también había diferentes posturas, según lo que los doctores quisieran probar. Algunos emprenderán una batalla encarnizada contra la religión y las supersticiones. Otros pondrán el énfasis en demostrar la tesis de la histeria constitucional, tomando en cuenta, por ejemplo, el alto porcentaje de casamientos consanguíneos en el poblado de Morzine. También están los que adoptaron una visión más "sociológica", señalando que, debido a la fuerte migración masculina que había padecido la aldea, las mujeres debían arreglárselas solas para realizar las tareas pesadas, y que la falta de hombres tornaba particularmente opresiva la situación de las jovencitas que ya no tenían la misma perspectiva que sus madres y abuelas de casarse ni de heredar un patrimonio, pero que, a diferencia de los hombres, permanecían en el lugar que la tradición había previsto para ellas, y no emigraban intentando probar fortuna en otra parte.

Esta postura médica se reflejó en programas de educación y esparcimiento, en la instalación de bibliotecas públicas, que también formaron parte de las estrategias médicas instrumentadas en Morzine, cuando las medidas autoritarias se revelaron insuficientes o ineficaces. Anticipándose en más de un siglo a algunos programas de reeducación o adaptación, que tanta vigencia tienen en la actualidad, los médicos más comprensivos, más tolerantes, tal vez intuyeron algunos de los conceptos 
modernos sobre el conflicto entre la tradición y el cambio. Tal vez también intuyeron que los síntomas de las jovencitas eran emergentes de la fragilidad de un equilibrio social amenazado por la migración de los hombres de la aldea. Lo que no pudieron responder, lo que aún hoy no puede responderse, es por qué cuando de fallas o de contradicciones, o de falta de elementos simbólicos para dar cuenta de las fallas o contradicciones, se trata, son las mujeres, y sobre todo las más jóvenes, las que lo expresan a través de sus síntomas, entre los cuales el rechazo a alimentarse ocupa casi siempre el primer lugar. ¿Por qué el diablo, que todos quieren expulsar de la aldea, el diablo de las nuevas ideas que afectan las tradiciones, se apodera del cuerpo de las hijas? A menos que se trate del mismo viejo diablo que habitaba en los cuerpos de las bisabuelas o tatarabuelas, torturadas o quemadas en las hogueras de la Inquisición. En todo caso nos encontramos frente a una paradoja: a través del diablo que las posee, las mujeres de Morzine terminarán por ingresar en la tan temida modernidad. Paradoja que aún hoy nos habita y que este libro intenta responder, en ese punto enigmático donde los cuerpos de las tan modernas jovencitas anoréxicas parecen habitados por un demonio al que no terminan de exorcizar." (Silvia Fendrik -- "Santa Anorexia" -- Capítulo I)

\section{Famosos/as y anoréxicos/as}

Pero no sólo en el campo espiritual o profano -llámese brujeril o posesión - se puede hablar de anorexia como enfermedad. Claro ejemplo fue Juliette Greco (1927 - ), famosa cantante francesa de los años 40-50 y musa de toda una generación de existencialistas; la padeció hasta caer casi en coma ${ }^{17}$. Igualmente podríamos citar a Simone Weil (1909 - 1943), filósofa, escritora y mística francesa, superviviente del holocausto nazi y después ministra del gobierno de su país ${ }^{18}$. Como vemos, mujeres todas, intelectuales, que tuvieron inquietudes trascendentales antes que cultivar el

\footnotetext{
17 Página web de Juliette Greco. http://perso.wanadoo.fr/juliette.greco/greco.htm

18 Simone Weil. http://webs.sinectis.com.ar/hgonzal/lit/sweil1.html
} 
cuerpo, ellas, como escribe San Sebastián Cabasés, "¿tal vez rechazadoras a priori del mismo y por ello precisamente excesivamente cultivadoras del espíritu o del intelecto?".

\section{JULETIE GRÉCO 요 et ses grandes chansons}

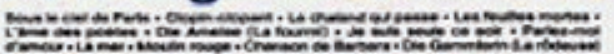

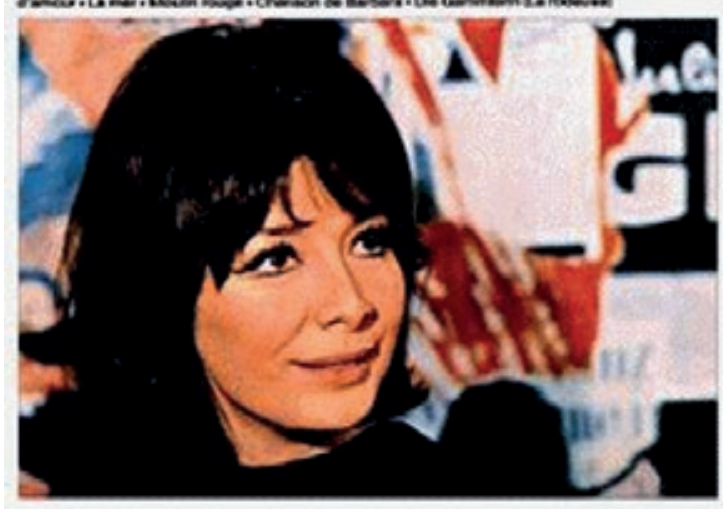

Imagen 24. A Juliette Greco la anorexia casi se la lleva a la tumba.

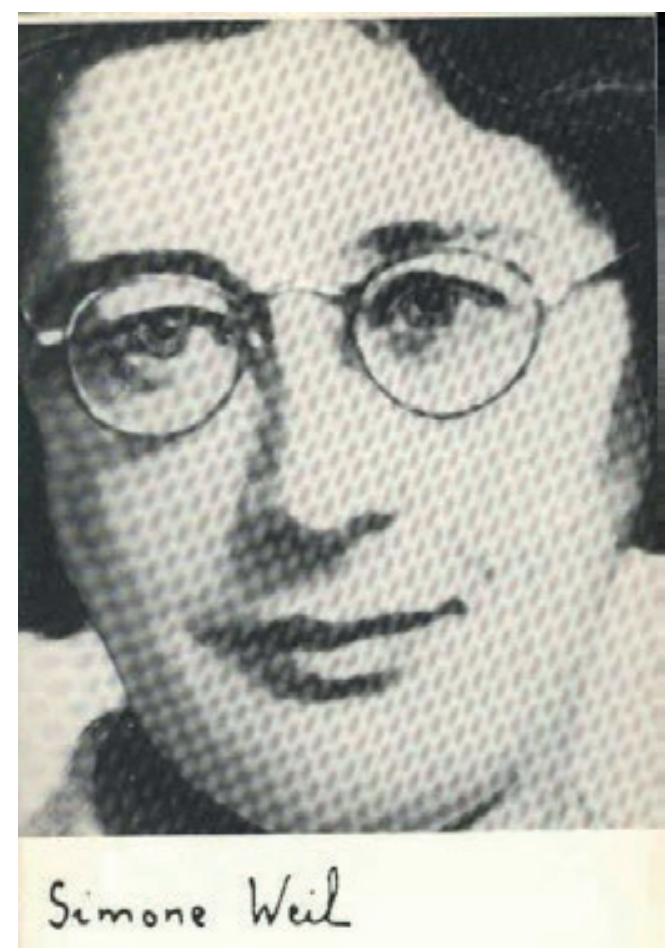

Imagen 25. Simone Weil, otra víctima de un mal que no perdona nada. 
Otra anoréxica purgativa, (tal vez bulímica o bulimaréxica) fue sin duda la princesa Diana de Gales (1961 -- 1997) que, como se sabe, falleció en circunstancias trágicas ${ }^{19}$. Su caso sí podría considerarse como el de un excesivo culto al cuerpo, la misma "enfermedad" que persigue a las "top model" y a muchas mujeres de la farándula internacional, cuyo rasgo común en todas ellas es una personalidad altamente conflictiva.

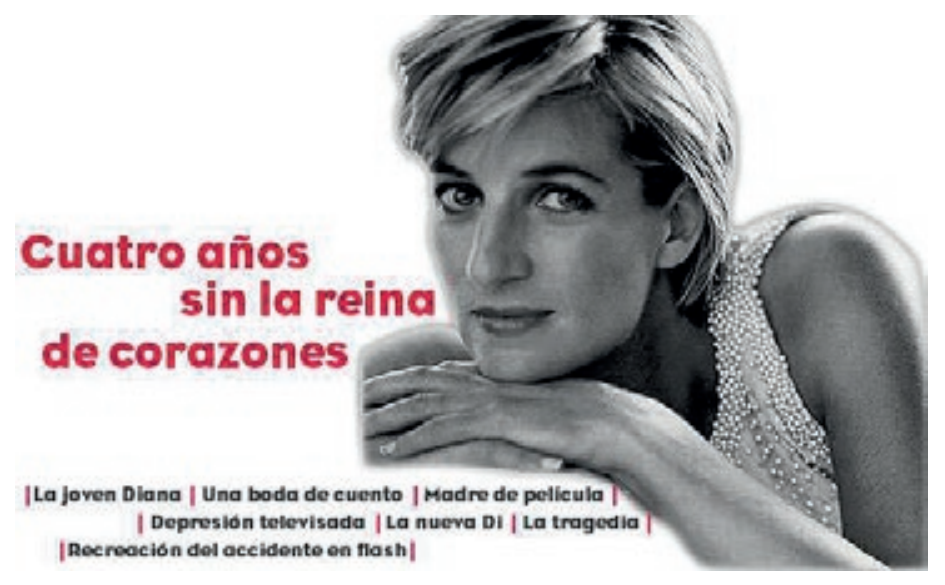

Imagen 26. La princesa de Gales se confesó anoréxica debido a sus problemas emocionales causados por la infidelidad matrimonial de su ex marido, el príncipe Carlos de Inglaterra, de quién se separó en un tormentoso divorcio.

Pero no sólo hablamos de mujeres, aunque las estadísticas las señalen más a ellas. Si de hombres se trata, también los hubo y muy famosos, en especial santos varones y grandes ascetas, empezando por San Francisco de Asís (1182 -- 1226), el "poverello de Asís"20, que se hizo célebre no sólo por su amor al prójimo y a sus "hermanos animales" sino también por los estrictos ayunos que seguía y su vida contemplativa y piadosa. Por otro lado, la historia de la Iglesia Ortodoxa Griega cuenta que uno de sus santos más conocidos (llamados por ellos boskoi) fue un asceta del siglo V,

\footnotetext{
19 "Cuatro años sin la reina de corazones". http://www.el-mundo.es/sociedad/aniversarioDiana/

20 "San Francisco de Asís: Su Vida". http://www.san-francesco.org/index_esp.html
} 
Simeón, "el estilita"21, que, según la tradición, vivió una década encaramado sobre una columna (los griegos llamaban "stilos" a las columnas, de allí el apodo de San Simeón) de diez metros cerca de la ciudad de Antioquia (Asia Menor), donde oraba de pie y se sometía a largos ayunos que sólo rompía una vez por semana para ingerir hierbas y un poco de agua. Tal retiro espiritual, sin embargo, no pareció mellar su salud, pues se dice que el santo vivió hasta los 106 años, aunque otra versión refiere que antes de subirse a "su columna" se retiró a una cueva donde vivió como ermitaño y que nació cerca del año 400 y murió en 459 de nuestra Era.

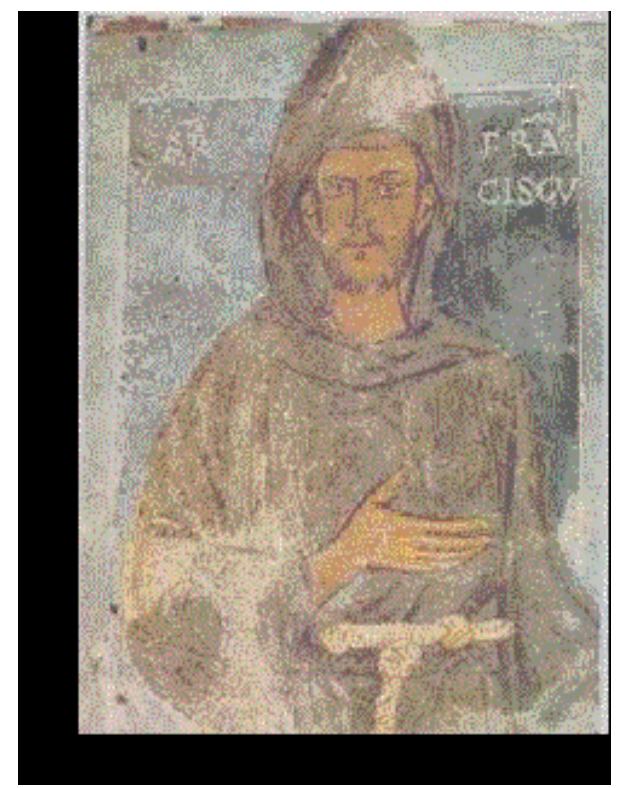

Imagen 27. Icono medieval de San Francisco de Asís.

\footnotetext{
21 "San Simeón 'el estilita', un santo fuera de serie".

http://www.geocities.com/Colosseum/Bleachers/2953/tierrasanta/estilita221001.htm
} 


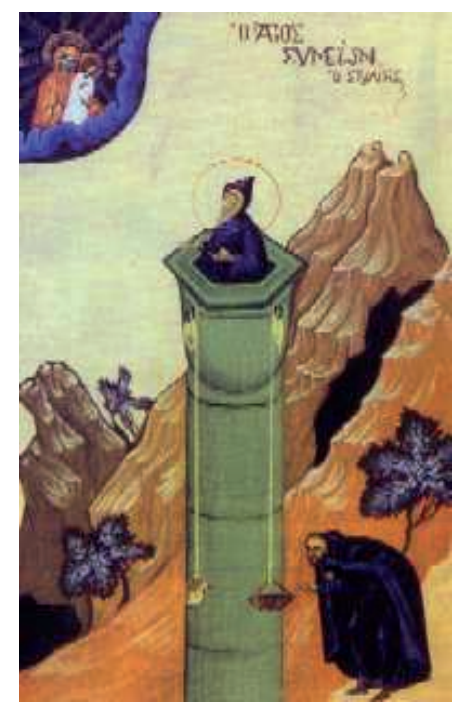

Imagen 28a. Esta miniatura medieval nos muestra a Simeón 'el estilita' sobre su célebre columna.

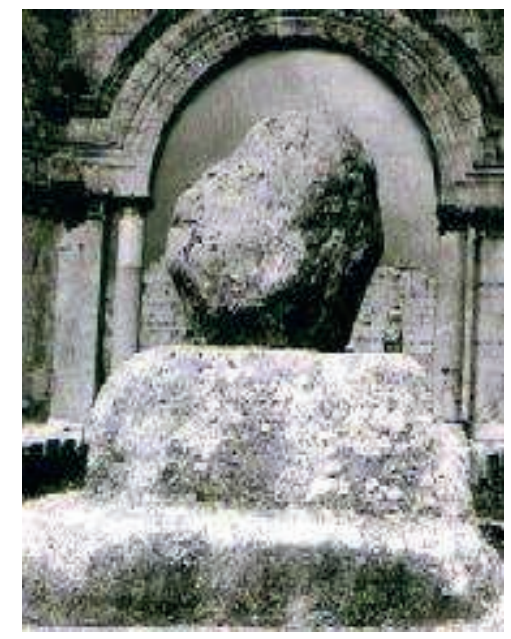

Imagen $\mathbf{2 8 b}$. Restos atribuidos a la columna donde San Simeón pasó diez años de su vida.

La historia también nos habla de personajes que no tenían nada de santos, entre éstos hay príncipes, reyes, y otros personajes que igualmente sufrieron las consecuencias del no comer por diferentes causas. Así, el famoso médico persa Avicena, (981 - 1037) cuenta la historia del joven príncipe Hamadham²2, "que se está muriendo por negarse a comer, preso de una intensa melancolía", aunque se presuma que este caso no sea otro que un cuadro depresivo.

22 "Avicena". http://www.iqb.es/HistoriaMedicina/Personas/Avicena.htm 


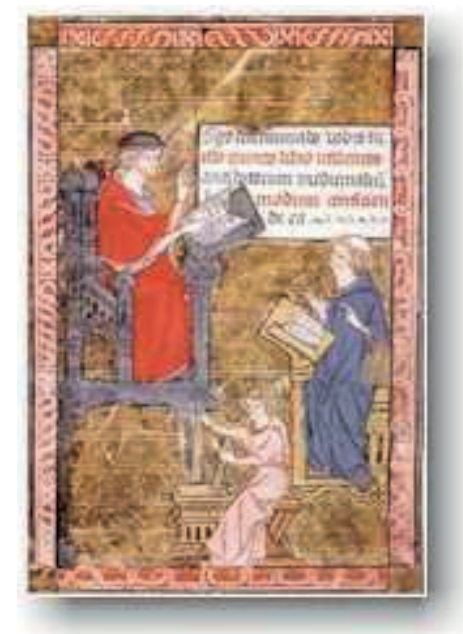

Imagen 29. El gran médico persa Avicena instruyendo a un discípulo. Miniatura medieval del Siglo X.

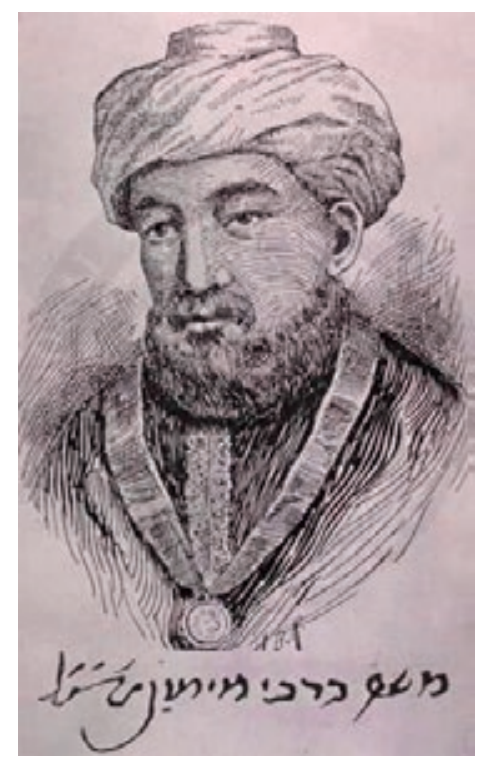

Imagen 30. Curioso retrado de Avicena con su rúbrica al pie. Fue uno de los primeros galenos en describir científicamente la anorexia.

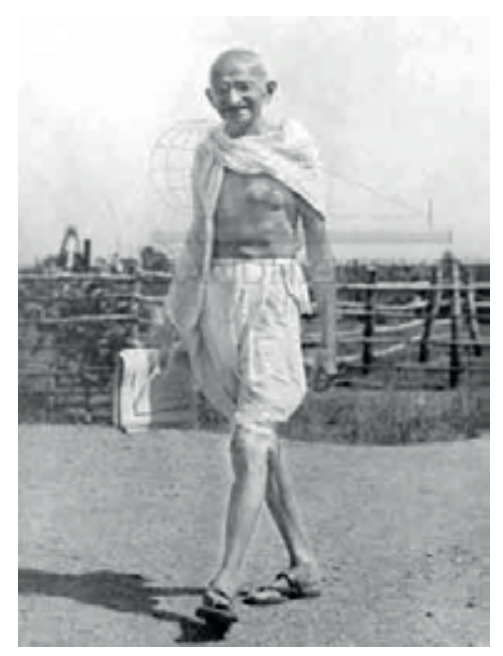

Imagen 31. Algunos creen que Mahatma Gandhi también sufrió anorexia, aunque nunca se ha demostrado que fuera así. Foto tomada en Sevagram Ashram, India. 1945. 
Se presume también que Mahatma Gandhi (1869 - 1948), artífice de la Independencia de la India, mantuvo durante su existencia una dieta probablemente más hipocalórica e hipoproteica que la de muchas anoréxicas restrictivas, aún siendo un hombre admirado por todo el mundo, tan lleno de profundas convicciones filosóficas y pacifistas como resuelto en el proceso independentista que llevó a cabo por su patria ${ }^{23}$. "Desde la óptica psicoanalítica, Gandhi habría sublimado sus pulsiones primarias, dando lugar a su 'espiritualización' y transformación en ideales, acompañado todo ello de pragmatismo y coherencia a la hora de llevarlos a la práctica- ¿Fue Gandhi un anoréxico? No es fácil responder a esta pregunta desde planteamientos fenomenológicos e historicistas de lo que suponen estas patologías, si bien, manejando los manuales diagnósticos de consenso actuales la respuesta es que no. La misma pregunta cabe hacerse de otros tantos personajes históricos en campos como la religión, el arte, la literatura y otros.", escribe San Sebastián Cabasés.

\section{El pasado de un futuro incierto}

\subsection{Habla la Antropología (Las brujas no comen lentejas... pero si "vuelan")}

El relato de la extraña experiencia de Morzine (Ver "Las poseídas de Morzine" -Capítulo VI), recogido por Silvia Fendrik, ha llevado a muchos autores a replantearse al tema de anorexia y su relación con las mujeres de la Edad Media, en especial de las santas, las brujas y las poseídas, enmarcando un fenómeno que, al margen de lo espiritual o lo profano, ha sido siempre un tópico delicado contra el cual se han estrellado muchos intentos por desvelar el misterio de su razón o sinrazón, peor aún cuando se quiere hacer una conexión entre el comportamiento de estas mujeres y los trastornos alimentarios.

Entonces se preguntan qué hay de cierto en aquellas versiones del pasado que hablan de tan insólitos personajes, contemporáneas, que sino compañeras en algunos casos,

23 "About GandhiServe Foundation". http://www.gandhiserve.com/information/about_gandhiserve/about_gandhiserve.html 
de mujeres que decían vivir del aire, sin comer, argumentando que Dios les daba fuerzas, o al demonio, como era achacado en algunos casos. Entonces, con la Licenciada Liliana Aguirre24, miembro de la "Escuela Argentina de Psicoterapia para Graduados", nos preguntamos ¿es la anorexia un fenómeno de la pos-modernidad? o, acaso es, como algunos dicen, una patología nueva para el análisis? ¿Y cómo se podría explicar entonces la contradicción que se abre cuando, a pesar de lo que se dice, el pasado grita para que escuchen su tragedia... que es la misma de este ahora?

"¿Es la anorexia (única y exclusivamente -- N. de R.) un fenómeno de la posmodernidad?" se pregunta la psicóloga Liliana Aguirre. ¿La anorexia - repetimos desconcertados - es una enfermedad exclusiva de nuestro desconcertante presente, como nos dicen algunos? ¿Realmente la anorexia es sólo el presente de nuestro ahora... o es acaso el presente de un pasado? Pero el mito de que se trata de una enfermedad actual, es decir, propia de nuestro tiempo, parece cojear cuando se la pone frente a la historia. Enfrentada con los testimonios del ayer, la medicina, la moderna psicología, y aún la mismísima religión, tal idea se estrella con todo un cuadro de hambres, vómitos y flacuras crónicas. Entonces... "¿la anorexia - se sigue preguntando la doctora Aguirre - es una nueva patología que los analistas debemos conocer o es un modo de nominar síntomas muy antiguos?" Lo único cierto es que la historia grita desde el fondo de los tiempos... y nos dice: "¡La anorexia es una patología vieja que nos señala un modo de nominar síntomas muy viejos que debemos conocer para poder entender nuestro presente... y saber cómo enfrentar una tragedia!"

$(\ldots)$

"En el siglo XIX cuando las posesiones demoníacas se creían desaparecidas - sigue escribiendo la doctora Aguirre - se produce un fenómeno que dio en llamarse: "Las

24 "Patologías Actuales". Publicado por "Reuniones de la Biblioteca" - Red de Investigación en Psicoanálisis. http://www.reunionesdelabiblioteca.com/patoligias_actuales_aguirre.htm 
poseídas de Morzine", algunas jovencitas y más tarde muchas otras mujeres, casi la mitad de la población femenina comienzan a sufrir ataques en los que insultan, se arrastran por el piso y se niegan a comer, vomitando cada vez que lo hacen. Exigen ser exorcizadas, pero la Iglesia no responde del mismo modo en que lo hizo dos siglos atrás cuando practicaba el exorcismo y la caza de brujas Esta vez reconoce que las brujas no existen y que se trata de enfermas, no de poseídas; por lo que recurre a la intervención médica y sanciona a los miembros del clero que siguen practicando el exorcismo.

Es la primera vez que el saber médico prevalece sobre las creencias religiosas y populares. Diez años más tarde Charcot comienza a transmitir en la Salpetriere (1882) sus conclusiones sobre la histeria. Freud rompe con el saber médico de su época, escuchando el síntoma histérico como el padecimiento de un cuerpo no de un organismo, hace hablar al síntoma y apuesta a la cura por la palabra.

Un largo camino se ha recorrido, F. (Freud) parece advertirlo en una carta que envía a Fliess, dice: ¿Qué me dices de ese comentario según el cual mi flamante prehistoria de la histeria ya había sido archiconocida y publicada aunque hace de esto varios siglos? ¿Recuerdas que siempre insistí en que la teoría medieval de la posesión era idéntica a nuestra teoría de la escisión de la conciencia? Pero ese diablo que se posesionaba de sus míseras víctimas ¿Por qué fornicaba siempre con ellas y de manera tan repugnante? ¿Por qué esas confesiones arrancadas bajo tormento son tan similares a las que mis pacientes me cuentan en el tratamiento psicológico?"

Y en la siguiente:

La conexión con la brujería cobra cada vez más vida y creo que es muy acertada. El vuelo de las brujas está explicado: la escoba sobre la cual cabalgan probablemente sea Monseñor Pene. ¡Si tan sólo supiera por qué el esperma del diablo siempre es 
calificado como frío en las confesiones de las brujas! Encargué un ejemplar de Malleus Maleficarun (El martillo de las brujas). (1489).

Los autores de este texto fueron los curas dominicos que hicieron un registro muy detallado de la vida de las santas, en el que el tema de la comida ocupa un lugar central. Este escrito les ha servido a los inquisidores para justificar la caza de brujas.

Los inquisidores las tildan de brujas, F. (Freud) frente a un cuadro que el considera idéntico produce otra significación. Esta significación y no la manifestación sintomática sería "lo nuevo".

Interesante planteo el de F. (Freud), en el que encuentra relación entre las brujas y poseídas de siglos pasados y las histéricas actuales, actuales de hace 113 años.

En los historiales de sus pacientes histéricas F. (Freud) describe la negativa a comer, así como en la sintomatología de la neurosis de angustia los ataques de bulimia.

Bulimia y anorexia están considerados como síntomas neuróticos desde los comienzos de la teoría psicoanalítica.

Hay testimonios sobre las vicisitudes de las conductas alimentarias de algunas santas que preocupaban a la Iglesia.

Raymond de Capua fue designado como guía y confesor de Catalina de Siena, a quien trató diariamente durante cuatro años para vigilarla por su negativa a comer y los vómitos provocados cuando lo hacía. Esta conducta debía ser controlada para proteger a la iglesia de una posible herejía. 
Sus ayunos comenzaron a los 16 años, sólo tomaba un poco de agua fría y algunas hierbas.

Dice su confesor: "cualquier alimento debía ser expulsado de su estómago y, para hacerlo, se introducía tallos de hinojo u otras plantas en la garganta".

Sta. Clara de Asís caminaba descalza, dormía en el suelo y hacía ayuno varios días a la semana.

A menudo estaba seriamente enferma al punto que el propio San Francisco, de quien se conocen sus prolongados ayunos, le exigía que comiera aunque fuera un pequeño trozo de pan cada día.

Estas circunstancias alcanzaron notoriedad y se sabe que, por lo menos, 17 santas intentaron llegar a los mismos extremos que Clara.

¿Qué diferencia habría entre la identificación de las jovencitas de su época a Santa Clara y la de las jóvenes de hoy a Claudia Schiffer por ejemplo?

El psiquiatra francés Lasegue denominó por primera vez en el siglo XIX estas formas extremas de privación alimentaria: anorexia histérica. Casi al mismo tiempo el psiquiatra ingles Gull la llamó: anorexia nerviosa, mientras que la denominación vulgar fue fansting girls (chicas ayunadoras.)

Parece que estos síntomas no son propios de los tiempos posmodernos ya que han sido descritos y nominados en distintas épocas de la historia: brujas, santas, histéricas, anoréxicas, parecen ser algunos nombres que se le han dado a estas mujeres problemáticas que no se ajustan al discurso dominante de la época. 
Respecto del ataque de pánico considero que sucede algo similar.

En la Neurastenia y la Neurosis de angustia, F. (Freud) describe los síntomas de la neurosis de angustia:

Excitabilidad general: una elevada excitabilidad indica siempre acumulación de excitación o incapacidad para resistirla.

Espera angustiosa: Temor a contraer una enfermedad o sufrir alguna desgracia, es lo que denomina: "ansiedad, tendencia a la visión pesimista de las cosas"

La espera angustiosa puede manifestarse como ataque de angustia. Tal ataque puede tan sólo consistir en una elevada angustia, o ir unida a la idea de muerte.

Los pacientes padecen: palpitaciones, taquicardia, disnea, sudores, bulimia, vértigo locomotor y pavor nocturno.

Este cuadro se diagnostica actualmente como "ataque de pánico."

(...)

\section{$\underline{\text { Mini-epílogo }}$}

Sin duda, tal presunción de negar el pasado de la anorexia parece cosa de locos. No es nuevo lo que es viejo... tampoco nuestra absurdez. Después de las santas y las brujas (y las poseídas de Morzine), el diluvio...

El centímetro o los centímetros, si tanto se preocupan los obsesionados por la figura femenina, va la advertencia: ¡Cuidado! El archifamoso 90-60-90 puede ser sinónimo de perfección... o el punto del no retorno. 


\subsection{Habla la Sociología (la madre del cordero)}

\subsubsection{Sacerdotes y psiquiatras: balada para no comer}

"Último momento: En un nuevo documento titulado " Sobre todo tipo de exorcismos y suplicas", aun no traducido del latín, la Iglesia recomienda a los exorcistas que recurran a los psicólogos o a los psiquiatras para poder diferenciar la histeria de la posesión diabólica. Sin embargo, esto no es nada nuevo. Ya en el siglo pasado cuando la Iglesia cedió parte de su poder a la medicina, las consultas con los psiquiatras estaban a la orden del día...

Hacía apenas cien años había finalizado la caza de brujas que provocó la muerte en la hoguera de millones de mujeres acusadas de brujas - (el último caso se registra a fines del siglo XVIII). En las posesiones colectivas del siglo XIX, - la más célebre ocurrió en la aldea francesa de Morzine - la Iglesia ya había llamado en su auxilio a los psiquiatras. La necesidad de distinguir entre la verdad y el fraude - origen de la moderna interconsulta con la psiquiatría- tiene antecedentes mucho tiempo atrás, a fines de la Edad Media, cuando cambiaron los cánones teológicos que habían regido durante el Medioevo y se aceptó como una realidad la intervención del Demonio en asuntos terrenales o sea su poder de apoderarse de cuerpos y almas. Antes, durante la baja Edad Media, el Canon Episcopal, establecía que el Diablo existía pero no tenía poder para entrar en contacto con los humanos. En ese entonces las brujas - siempre las hubo- eran consideradas perversas o desamparadas mujeres que creían estar poseídas por el demonio, pero se pensaba que eran ilusiones o trastornos mentales que afectaban a jovencitas ignorantes o a viejas melancólicas. Es recién en el siglo XII, gracias, entre otros, a la gestión de Santo Tomas de Aquino, que las brujas y los brujos comienzan a tener existencia tangible $y$ en consecuencia deben ser exterminados. Se vuelve entonces imperioso distinguir los estados místicos de los casos de posesión diabólica para detectar a los agentes terrenales del demonio, los brujos, pero sobre todo las brujas.. Algunos médicos denunciaron esto como un cruel 
retroceso de la Iglesia y le recordaron que se trataba de alteraciones mentales, de alucinaciones. Es el caso del Dr. Juan Wier o de Reinaldo Scoto, quienes también fueron perseguidos por la Inquisición, acusados de no creer en brujas y de cuestionar por lo tanto los nuevos cánones eclesiásticos.

Acorde al aire de los tiempos en que la histeria es creada como cuadro y divulgada por la psiquiatría del siglo XIX, la Iglesia recurre a ella para evitar la confusión entre la verdad y el fraude, entre locura humana y posesión. Su principal e imperiosa preocupación es diferenciar la pseudo-mística, producto de estados nerviosos patológicos, de la falsa mística, objeto de una intervención diabólica, de la mística auténtica, que es la única capaz de operar milagros verdaderos.

Esta clasificación data del siglo XIX y establece que en el primer caso siempre deberá recurrirse al médico. En los otros casos la Iglesia se valía de sus propios métodos. La confrontación de sus propias opiniones y métodos con los de la psiquiatría le permitieron a la Iglesia certificar retroactivamente la santidad de Teresa de Ávila, mientras los psiquiatras, que también sacaban sus propias conclusiones sobre santas y brujas de otros siglos, no dudaron en diagnosticarla como patrona de las histéricas ${ }^{25}$.

\subsubsection{Médicos y sacerdotes}

"Durante siete siglos, en los que fue aumentando el poder de la Inquisición, la Iglesia se encontró una y otra vez frente a un mismo dilema. Tanto las autenticas místicas poseídas por Dios- como las falsas -poseídas por el Diablo, acreditaban poderes sobrenaturales, entre los que se destacaba en primer lugar, la facultad de poder vivir

\footnotetext{
${ }^{25}$ Artículo Publicado en el Diario Perfil, de Buenos Aires. Junio de 1998.Citado por la autora en el Portal Ambrosía: http://www.sfendrik.com.ar/ambrosia/index.htm
} 
sin alimentarse. En el siglo pasado la primera razón para consultar a los psiquiatras era esa: multitud de jóvenes mujeres dejaban de comer y por ese motivo se adjudicaban -y les eran adjudicados- poderes sobrenaturales. Ya no se creía en la brujería, la práctica generalizada de exorcismos preocupaba a la Iglesia y muy pocos sacerdotes estaban autorizados a llevarlos a cabo.

Aunque las sádicas torturas autorizadas por los tribunales eclesiásticos habían quedado atrás, los métodos inquisitoriales reviven en los interrogatorios y tratamientos inventados por la psiquiatría, para detectar y alertar contra los peligros que representaban las modernas histéricas del siglo XIX, entre cuyos síntomas se destacaban graves trastornos alimenticios. Agujas y pinchazos, miradas clavadas sobre las pacientes sospechosas de histeria y todo tipo de presiones para hacerles confesar que lo de ellas era puro teatro, encierros y castigos, son algunos de los apenas disfrazados métodos inquisitoriales revividos por la psiquiatría del siglo pasado.

¿Qué ocurre hoy? Una vez más la Iglesia parece haber olvidado su propia historia, tanto la de la temprana Edad Media, en la que la creencia en brujos y brujas era adjudicada a mentes enfermas, como la ignominiosa de la Inquisición, o el recurso a la psiquiatría ya a fines del siglo pasado.

Lo raro es que también los psiquiatras y psicólogos actuales ignoran que la anorexia tiene una historia de muchos siglos. Influidos por la modernidad que cree que todo ocurre en este fin de milenio la atribuyen a la moda de la delgadez, y persiguen a las pacientes amenazándolas con slogans de muerte para curarlas, o delegan sus responsabilidades en especialistas que sólo ven en ellas almas rebeldes y caprichosas a las que es necesario dominar y cuerpos desnutridos a los que es necesario alimentar. 
Si el nuevo manual de exorcismos llega a ser traducido del latín sabremos si la inanición extrema también continúa, como lo fue durante siglos- siendo un signo de posesión (ora divina ora diabólica) para la Iglesia. Mientras tanto muchos médicos y psicólogos combaten la religión ligth, sin darse cuenta que a su manera siguen, en los albores del nuevo milenio, persiguiendo a las jovencitas anoréxicas como si se tratara de autenticas poseídas"26 Silvia Fendrik.

\subsection{Habla el Psicoanálisis (Anorexia del somatismo)}

"(...) ¿Cómo juzgar a esas mujeres que trataban de mantener la pureza del espíritu y el horror a lo corporal tratando de conseguir una imagen sin formas, esto es, un cuerpo asexual? La Iglesia se inclinó en muchas ocasiones por la santificación, en tanto que estas mujeres, ejemplo de vida, basaban su existencia en ese ideal de la época gobernado por la extremada pureza y el ascetismo.

Hay que tener ya en cuenta, a partir de este momento, cómo la actitud de rechazo frente a la imposición del oro representa una forma de preservar el deseo propio (como trataré de desarrollar más adelante). Y, por otro lado, hay que fijarse en cómo el síntoma, (en este caso, el rechazo al alimento), puede recibir connotaciones muy diversas en función del discurso de la época, desde la santificación y la admiración a la condena y el intento de represión.

De esta forma, podemos ya empezar a apuntar que el síntoma psíquico como tal siempre se construye pensando en el Otro del discurso del momento y con los instrumentos de conocimiento de cada época. Así, la histérica en la Edad Media se veía como una poseída que gozaba con alucinaciones místicas en un momento en el que predominaba el discurso religioso como Amo del Saber. A su vez, la histeria de

\footnotetext{
${ }^{26}$ Artículo Publicado en el Diario Perfil, de Buenos Aires. Junio de 1998.Citado por la autora en el Portal Ambrosía: http://www.sfendrik.com.ar/ambrosia/index.htm
} 
finales del siglo XIX entregaba su cuerpo doliente, con quejas corporales A su vez, la histeria de finales del siglo XIX entregaba su cuerpo doliente, con quejas corporales, a la mirada del saber médico, que, mediante la hipnosis y la sugestión, construía y completaba toda una teoría científica. Y la histeria de finales de este siglo nos muestra, con su cascada somatizadora y rebelde, a los ojos de nuestro saber, un cuerpo sin lesiones que busca en la enfermedad orgánica y en el amparo de la técnica la confirmación de este saber actual que, dominado por lo científico, trata de alejar toda idea de psicologismo del malestar humano.

Alucinaciones religiosas en la época medieval, personalidades múltiples y cegueras conversivas en los albores de la ciencia moderna, así como somatizaciones múltiples en este final de siglo técnico-científico, dan cuenta de síntomas construidos para el Otro del discurso de la época.

De esta manera, podemos decir que cada época, gobernada por su discurso, hace que el síntoma construido con palabras se muestre permeable a la palabra de poder del momento y lo garantice, ejerciendo este discurso, a su vez, una configuración específica con las propias configuraciones clínicas. Y es que la anorexia, como síntoma, no es ajena a esta permeabilidad del discurso social; $\mathrm{y}$, a pesar de que quien la padece pueda alcanzar la muerte en ocasiones por este acto, su rechazo al alimento adquiere muy distintas connotaciones, dependiendo del momento histórico: desde el ensalzamiento heroico y la santificación por desdeñar un estilo de vida que llama a la voluptuosidad hasta la imposición del alimento, contra su voluntad, a ese cuerpo que se deja morir y que quiere ser fiel a un ideal de delgadez, en donde el cuerpo transparente y sin formas reclama una existencia de pureza. 
Son éstas, pues, las distintas maneras de articular y comprender un problema, una queja, un malestar (en este caso, el rechazo al alimento), en función de las ideas culturales de cada época. ${ }^{27 "}$ Luis-Salvador López Herrero.

\subsection{Habla la Medicina (¿Anoréxicas? ¿Modelos? No Anoréxicas en} Recuperación / No Modelos Exitosas)

"La delgadez extrema de las modelos que triunfan impone una estética anoréxica peligrosa de imitar. La loca "anatomía de la mujer superior" y el aumento de los trastornos alimentarios.

La verdad aflora en el backstage de los largos eventos. Allí se advierte cuántas viven de la lechuga con ketchup. Y en esto no hay simbología. La receta más exitosa del momento prescribe qué hacer cuando se engordó un kilo: suprimir todo alimento hasta haberlo adelgazado.

¿Por qué habrían de marginarse las criollas de la metodología aplicada por las número uno? "The world's best kept diet secrets" se convirtió rápido en best seller en los Estados Unidos. Por curiosidad o para emularlos, las lectoras se enteraron a través del libro de que la exitosa Christie Brinkley se limita a una dieta líquida de jugos de frutas y verduras cuando se prepara para una nueva campaña. Que la patinadora Peggy Fleming come una tostada de desayuno y media taza de arroz de cena. Y que la top Elle MacPherson elige entre almorzar o cenar, pero nunca las dos cosas, aunque su rutina incluya 500 sentadillas (ejercicio para los muslos) por día.

¿Quiere lucir como una modelo o una estrella de cine? Pues bien, adquiera el índice de masa muscular de un chico de 8 años.

\footnotetext{
27 "Anorexia: Comer nada. Una Perspectiva Psicoanalítica".Publicado por la Asociación Española de Psiquiatría y Psicología de la Infancia y la Adolescencia: http://www.pulso.com/aen/numero72/72_colaboraciones1.pdf
} 
Los secretos revelados en el libro incluyen consejos delirantes de cómo no tragar: los cuerpos exitosos mastican y escupen para no engordar. Se sugiere bajar la temperatura de la habitación de noche: el frío lo hará quemar más calorías mientras duerme. Y llevar un pañuelo perfumado en el bolsillo para aspirarlo cuando pase frente a una panadería para no tentarse.

Si estas ideas resultan desopilantes, la locura exponencial asoma desde las páginas web "pro anorexia" o como lo llaman las iniciadas "pro Ana". Son unos 400 web sites con denominaciones como "el cuerpo perfecto", "obsesión con la delgadez" o "anorexia para principiantes", con estrategias para eludir a médicos y parientes que interfieran en su máxima ideológica: la muerte es mejor que la obesidad.

El descontrol. Las primeras referencias a la enfermedad datan del 1200, época de la que se conocen descripciones de religiosas que ayunaban y eran llamadas "santas anoréxicas". "A partir de esos casos comienza a observarse una distorsión sobre lo que se considera el ayuno, pasando de lo místico a lo patológico", explica la doctora Mabel Bello, quien junto a un grupo de médicos del Hospital de Gastroenterología de Buenos Aires creó Aluba (Asociación de Lucha contra la Bulimia y Anorexia) cuando empezaron a aparecer los primeros casos en 1985. "Nos traían chicas al borde de la muerte que no tenían un lugar dónde tratarse. Entonces creamos un tratamiento transdisciplinario basado en la autoayuda y en una activa participación de la familia", recuerda.

Hoy, la patología se atiende en ese y otros centros de salud con novedades alarmantes: "Durante el primer semestre del 2001 se triplicó el número de consultas espontáneas realizadas por padres de niños de 3 a 6 años", dice Bello.

Me gusta ser mujer. El solo hecho de ser mujer ya constituye un factor de riesgo. El 90\% de las afectadas lo son. De hecho, el $85 \%$ de personas que en el mundo pagan 
tratamientos para estar flacas son mujeres. Más del $60 \%$ de quienes se someten a cirugías plásticas, también. La necesidad de adelgazar a toda costa sostiene un negocio que genera 50 millones de dólares al año en todo el mundo. Nunca antes la búsqueda de la belleza había obligado a luchar con semejante énfasis contra la propia biología.

La distancia cada vez mayor que existe entre la mujer común y las modelos hace que casi nadie ya se sienta satisfecha con su cuerpo. Entre las pocas certezas que se tienen sobre los orígenes de esta epidemia -se habla de un cruce de factores genéticos, familiares, psicológicos y socioculturales- lo cierto es que a la anorexia y a la bulimia se llega siempre por el camino de las dietas.

Según la Organización Mundial de la Salud, el 60\% de las mujeres hace dieta y un 75\% se sienten gordas aunque no lo estén. En el Occidente sobrealimentado emerge la paradoja: el hambre autoimpuesto es nueva virtud.

A los judíos que fueron exterminados por los nazis en los campos de concentración de la Segunda Guerra Mundial -muchos murieron a causa del hambre y la desnutrición- se les suministraba una deficiente dieta de entre 700 y 1.700 calorías: la mayoría de las dietas de moda que siguen miles de personas sin control no superan las 1.000 calorías diarias.

Tres historias. Se dejaron fotografiar y dieron sus nombres reales sabiendo que, además de los desconocidos, mucha gente que las conoce descubriría su parte en esta historia. Las empujó las ganas de ayudar a otras mujeres, de prevenirlas.

María Inés López ahora estudia psicología. Le molesta escuchar el comentario más oído entre sus pares de la facultad: "Estoy regorda". Porque ella combate desde 
hace tres años la desmesura de las dietas obsesivas, los laxantes y el hábito de no permitirse menos de cuatro horas de gimnasia por día.

Martina G. B., diseñadora gráfica, está aprendiendo a vivir sin contar calorías. "Mi vida consistía en hacer cálculos de lo que comía, hacer ejercicio y pesarme tres veces por día". Abusaba de medicamentos para adelgazar, no iba a reuniones en las que habría comida, se encerraba a dormir y peleaba con sus amigos, con su familia. "Ahora estoy aprendiendo a disfrutar de la gente, de la vida, de la comida, y aprendí que los parámetros sociales no son saludables, que puedo no entrar en los talles de una marca, pero eso no me va a hacer empezar una dieta estricta ni me va a arruinar el día."

Cecilia Frezia cuenta que le decía a su familia "me estoy cuidando" cuando, en realidad, quería decir "estoy haciendo dieta". Y no muy razonable. "Yo sabía cuánto tiempo de gimnasia tenía que hacer para gastar un alfajor. Tenía pánico a engordar."Cecilia estaba convencida de que ser feliz era ser considerada una "diosa". "Pero cuando llegaste a pesar 48 te sentís igual de mal, entonces buscas llegar a los 45 y no puedes parar."

Futuro incierto. Aunque los hombres no tienen modelos tan uniformes a imitar, también son susceptibles de padecer la tiranía estética. En el libro "El complejo de Adonis" los psiquiatras norteamericanos Harrison Pope y Katharine Phillips descubrieron que a casi la mitad de los hombres ya les disgusta su apariencia. Bien harían en darse cuenta a tiempo de que ni siquiera empatar al otro sexo en esta carrera vale la pena."28 Perfil, 2000.

\footnotetext{
${ }^{28}$ Revista Noticias - Publicación Semanal de Editorial Perfil (12-9-2000).Buenos Aires. http://www.noticias.uol.com.ar/edicion_1290/nota_02_2.htm
} 


\section{La Medicina descubre la "caquexia de Simmonds"}

Esta enfermedad tan curiosa, que confundía a todo el mundo y ponía de vuelta y media a la Iglesia por el caso de las religiosas que no comían, siempre existió y despertó la curiosidad médica, ocupando lugar destacado en la literatura especializada. En el año 1500, el médico Simone Porta ya había descrito algunos casos por él observados, que podrían identificarse con una anorexia nerviosa. Después de Avicena, los primeros textos que tratan el tema datan del siglo XVII. En 1689, el médico inglés Richard Morton fue el primer autor en realizar con todo detalle la descripción clínica de un caso de anorexia nerviosa purgativa en un texto titulado "A Treatise of Compsumtions", refiriéndose a una joven paciente llamada Miss Duke. Morton denominó a la enfermedad como "consunción nerviosa" y en su escrito habla de anorexia, pérdida de peso, amenorrea, estreñimiento e hiperactividad, sin encontrar alteraciones físicas que lo justifiquen. Morton atribuyó estos desarreglos a la tristeza y a las preocupaciones.

La doctora Irizar Lezámiz Aróstegui ${ }^{29}$ cuenta que la primera definición de la anorexia histérica se dio en 1875, cuando, siguiendo los pasos de Morton, Gull en Londres y Lassegue en París, hicieron descripciones de cuadros de anorexia tan precisos que se han convertido en textos obligados para los estudiosos de los trastornos alimentarios. Ellos llamaron a esta enfermedad "apepsia histérica" y "anorexia histérica" respectivamente y sindicaron a la histeria como la gran culpable, con lo que quedaba definida como "anorexia mental" o "trastorno consuntivo", un mal mortal en casi todos los casos, descartando su origen orgánico. Ellos, al hablar de sus pacientes, señalaron que en estas chicas existía una negación perversa a comer. Por su parte, Lasegue $^{30}$ observó que la enfermedad ocurría en mujeres adolescentes y comenzó a

\footnotetext{
29 "Homeopatía Clínica, Revista de Formación Médica Continuada.Anorexia Nerviosa - Sociedad Española de Medicina Homeopática. http://www.campuscic.net/semhrevista/VerArticulo.asp?idarticulo=304\&idnumero=3

30 "Los Orígenes de la Anorexia Nerviosa" Licenciada Valeria Matzkin (Buenos Aires). http://www.nutrinfo.com.ar/pagina/info/anorexi2.html
} 
investigar la conducta de la familia ante el rechazo de la adolescente a ingerir alimentos.

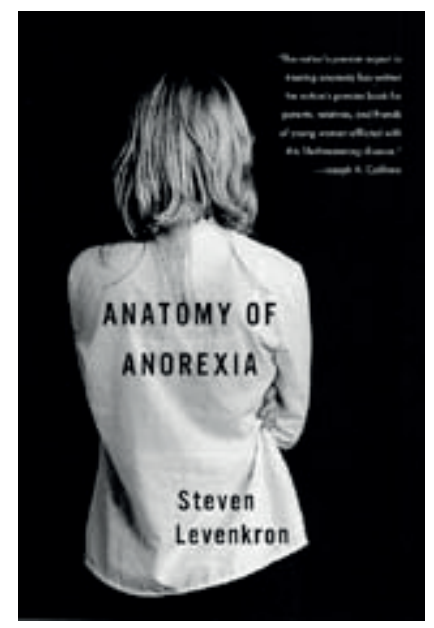

Imagen 32. Más son los psicólogos que los médicos quienes tratan de entender los viejos trastornos de la comida ${ }^{31}$

A comienzos del siglo XX, esta enfermedad fue erróneamente confundida con insuficiencia pituitaria y se implementaron tratamientos invasivos con insulina y electroshock y en los años '30, con el auge del psicoanálisis, se exploraron las causas psico-sexuales de la anorexia nerviosa. El descubrimiento realizado en los años '40, de las secreciones hipofisiarias y de la función de la hipófisis como organizadora del sistema endocrino, parecía confirmar que la enfermedad tenía un origen mental y no orgánico, como se había supuesto. Menudo embrollo, pues, para el doctor Simmonds quien, en 1914, había llamado "caquexia hipofisiaria" a una difunción de la glándula hipófisis, sindicándola como la causante de la anorexia nerviosa. En otras palabras, para él todo era de origen orgánico. Entonces, para "salvar el honor", este especialista, conjuntamente con su colega, el doctor Sheehan, colocaron la anorexia como "caquexia hipofisiaria", por lesión de la ante-hipófisis, considerándose hasta los años '70 como una enfermedad endocrina con el nombre de "caquexia de Simmonds", una de cuyas manifestaciones es la anorexia nerviosa. Paralelamente, la

31 "Anatomy of Anorexia". http://www.wwnorton.com/NPB/nppsych/old/medical/anorexia.htm 
doctora Brunch, en Estados Unidos ${ }^{32}$, describió las características de la personalidad de los individuos que sufren anorexia nerviosa. Brunch observó aspectos comunes en los pacientes: la distorsión de la imagen corporal, el sentimiento de inutilidad e incompetencia y la incapacidad de interpretar y reconocer las necesidades corporales. En el año 1972, otra especialista, Marta Selvini, creadora del Instituto de Terapia de Familia de Milán (Italia) la define como enfermedad mental, como una psicosis y además como una psicosis familiar al considerar preciso tratar a toda la familia ya que la anorexia no es la única enferma.

\section{0. ¿Sabía usted que...?}

-En la actualidad hay 20 mujeres anoréxicas por cada hombre en el mundo occidental.

-La palabra "anorexia", que etimológicamente significa "pérdida de apetito", apareció por primera vez en la literatura médica para referirse a un síntoma en 1587 en un tratado francés sobre desórdenes alimentarios.

-El cambio estético de la estética a lo largo de la historia es dramático. En la época del Renacimiento (siglo XV) la figura femenina ideal para Boticelli tenía una talla de 1.58 cm, pesaba 52 kilos y su índice de masa corporal era de 20; durante el Barroco (siglo XVI), Tiziano pintaba en sus lienzos a una mujer con talla de $1.63 \mathrm{~cm}$, peso de 72 kilos y un IMC de 27; mientras que en nuestros días (siglo XXI), una típica modelo tiene una estatura de 1.79 de estatura, pesa 59 kilos y posee un índice de masa corpórea de 15.

-En la Baja Edad Media había en Europa 2.000 monasterios con una población de 30.000 miembros, la tercera parte de estos eran mujeres.

32 "Los Orígenes de la Anorexia Nerviosa" Licenciada Valeria Matzkin (Buenos Aires).

http://www.nutrinfo.com.ar/pagina/info/anorexi2.html 
-Freud describía el componente psicosomático de la anorexia como "una forma de melancolía prepuberal causada por conflictos sexuales reprimidos, donde la comida representa impulsos sexuales".

-En el siglo XIX, la desacralización de la medicina y la introducción del pensamiento científico incitaron la penalización de la restricción alimentaria, lo que permitió que la enfermedad sea reconocida como tal.

-En la actualidad, el $16 \%$ de los jóvenes occidentales sufre de algún trastorno alimentario.

\section{Apéndice}

Quemas de Brujas en la Europa Medieval y Moderna (Cuadro estadístico)

\begin{tabular}{|l|c|c|}
\hline \multicolumn{2}{|c|}{ La densidad de persecución de brujas en Europa } \\
(Behringer1998:65 f ) \\
\hline País & $\begin{array}{c}\text { Ejecuciones } \\
\text { (por cada mil) }\end{array}$ & Habitantes c/1600 \\
\hline Portugal & $7(0,0007)$ & 1.000 .000 \\
\hline Italia & $300(0,037)$ & 8.100 .000 \\
\hline España & $1000(0,076)$ & 13.100 .000 \\
\hline Países Bajos & $200(0,133)$ & 1.500 .000 \\
\hline Francia & $4000(0,200)$ & 20.000 .000 \\
\hline Inglaterra/ Escocia & $1500(0,231)$ & 6.500 .000 \\
\hline Finlandia & $115(0,238)$ & 350.000 \\
\hline Hungría & $800(0,267)$ & 3.000 .000 \\
\hline Bélgica/ Luxemburgo & $500(0,384)$ & 1.300 .000 \\
\hline Suecia & $350(0,437)$ & 800.000 \\
\hline Islandia & $22(0,440)$ & 50.000 \\
\hline Chequia/ Eslovaquia & $1000(0,500)$ & 2.000 .000 \\
\hline
\end{tabular}




\begin{tabular}{|l|c|c|}
\hline Austria & $1000(0,500)$ & 2.000 .000 \\
\hline Dinamarca/ Noruega & $1350(1,391)$ & 970.000 \\
\hline Alemania & $25000(1,563)$ & 3.400 .000 \\
\hline Polonia/ Lituania & $10000(2,941)$ & 1.000 .000 \\
\hline Suiza & $4000(4,000)$ & 3.000 \\
\hline Liechtenstein & $300(100,000)$ & \\
\hline
\end{tabular}

Fuente: Gustav Henningsen, Copenhague ${ }^{33}$

\section{Procedencia de las imágenes}

1. http://www.terra.com.pe/mundonuevo/images/rosa2.jpg

2. http://www.dominicos.org/op/Hagiografia/CATALINA.HTM

3. http://www.sfendrik.com.ar

4. http://www.sfendrik.com.ar/ambrosia/

5. http://witcombe.sbc.edu/willendorf/willendorfdiscovery.html

6. http://www.humanities-interactive.org/ancient/iceage/ex038_06a.html

7-8-9. http://www.encolombia.com/adipovol4no1_salon4.htm

10. http://www.uco.es/informa/local/cviva/119.html

11. http://perdidos.tripod.com.ar/bosch1.htm

11a. http://www.encolombia.com/adipovol4no1_salon4.htm

12. http://www.baiona.org/org/ga/b/07/index.html

13. http://www.devocionario.com/santos/siena_1.html

14. http://www.franciscanos.org/selfran66/epumbro.html

${ }^{33}$ Extraído de: "La Inquisición y la Brujería". http:// www.archimadrid.es/princi/princip/otros/docum/iglebru/iglebru1.htm 
15-16. http:/ / www.geocities.com/mysteryplanet2/CA/JdeArco.htm

17.http:/ / www.dartmouth.edu/ sorjuana/

18. http://www.cipecar.org/teresa.htm

19a. http:/ / www.devocionario.com/santos/avila_1.html

19b. http://orbita.starmedia.com/famosasx/x/schiffer/schiffer005.jpg

20. http://www.ociojoven.com/article/articleview/5945/1/101/

21. http:/ / www.artehistoria.com/frames.htm?http:/ / www.artehistoria.com /historia/contextos/1680.htm

22. http://www.focusonwomenshealth.com/images/Abanorex.gif

23. http://www.aet-taxi.com/es/galeriemorzine_es.html

24. http://website.lineone.net/ new-classics/assets/images/juliettegreco.GIF

25.http://hem.passagen.se/margaretabjorndahl/weil.h2.jpg

26.http://www.el-mundo.es/sociedad/aniversarioDiana/

27. http://www.san-francesco.org/index_esp.html

$28 \mathrm{a}-28 \mathrm{~b}$.

http://www.geocities.com/Colosseum/Bleachers/2953/tierrasanta/estilita221001.h $\underline{\mathrm{tm}}$

29. http://www.diabetesymas.com/Imagenes/Avicena-p.jpg

30. http://www.iqb.es/HistoriaMedicina/Personas/Avicena.htm

31.

http://www.gandhiserve.com/information/about_gandhiserve/about_gandhiserve .html

32. http://www.wwnorton.com/NPB/nppsych/old/medical/anorexia.htm 